\title{
O GÊNero Casearia No ESTAdo do Rio de JANeIro, BrasiL ${ }^{1}$
}

\author{
Ronaldo Marquete ${ }^{2,3}$ \& Angela Maria Studart da Fonseca Vaz ${ }^{2}$
}

\section{RESUMO}

(O gênero Casearia no estado do Rio de Janeiro, Brasil) O tratamento taxonômico das espécies do gênero Casearia ocorrentes no estado do Rio de Janeiro é apresentado. Foram realizadas observações de campo, coleta de material botânico e análise de coleções de herbários nacionais e internacionais. São apresentados chave de identificação, descrições, ilustraç̃̃es, dados sobre distribuição geográfica, floração e frutificação, nomes vulgares e comentários a respeito de cada táxon. Doze espécies foram reconhecidas: Casearia arborea, C. commersoniana, C. decandra, C. lasiophylla, C. luetzelburgii, C. melliodora, C. obliqua, C. oblongifolia, C. pauciflora, C. selloana, C. sessiliflora e C. sylvestris. C. luetzelburgii e C. selloana são registradas como novas ocorrências no Rio de Janeiro, enquanto $C$. sessiliflora é endêmica para o estado. Casearia sylvestris var. lingua foi tratada como sinônimo de Casearia sylvestris.

Palavras-chave: Florística, Flacourtiaceae, Taxonomia, Salicaceae, Samydaceae.

\section{Abstract}

(The genus Casearia in the state of Rio de Janeiro, Brazil) The taxonomic treatment of the genus Casearia Jacq. in the state of Rio de Janeiro, Brazil, is presented.The study is based on field work as well as on national and international herbarium collections. Descriptions, identification key, illustrations, geographic distribution, flowering and fruiting times, vernacular names and comments about each taxon are presented. Twelve species were recognized: Casearia arborea, C. commersoniana, C. decandra, C. lasiophylla, C. luetzelburgii, $C$. melliodora, C. obliqua, C. oblongifolia, C. pauciflora, C. selloana, C. sessiliflora, C. sylvestris. Furthermore, Casearia luetzelburgii and C. selloana are new records for Rio de Janeiro, while C. sessiliflora is endemic to the state. Casearia sylvestris var. lingua was treated as a synonym of Casearia sylvestris.

Keywords: Floristics, Flacourtiaceae, Taxonomy, Salicaceae, Samydaceae.

\section{INTRODUÇÃo}

Flacourtiaceae senso lato, compreende cerca de 86 gêneros e mais de 800 espécies, distribuídas nas Américas, África, Ásia, Malásia, Austrália e ilhas do Pacífico (Klein \& Sleumer 1984). No Brasil, a família possui 21 gêneros e 117 espécies distribuídas nos diferentes ecossistemas brasileiros, com grande capacidade de adaptação ao meio (Klein \& Sleumer 1984).

O gênero Casearia tem sido subordinado a diferentes famílias, do século XIX aos nossos dias, de acordo com conceitos diferenciados adotados por vários autores. De Candolle (1825) e Hooker (1867) o consideraram como um gênero de Samydaceae; Eichler (1871) de Bixaceae; Warburg (1894), Gilg (1925) e Macbride (1941) incluíram, também, os gêneros Bixa e Cochlospermum na circunscrição da família
Flacourtiaceae, enquanto Sleumer (1950, 1953 e 1980) manteve-o em Flacourtiaceae, excluindo porém, os gêneros Bixa e Cochlospermum. Judd et al. (2002) e APG II (2003), com base em estudos de biologia molecular, reconhecem as diferentes tribos de Flacourtiaceae em nível de família. Alford (2003), por sua vez, apresenta uma nova circunscrição em Flacourtiaceae mantendo Berberidopsidaceae, Lacistemataceae, Samydaceae (incluindo Casearia), Salicaceae e outras famílias à parte.

O gênero Casearia foi descrito por Jacquin (1760), sob o basiônimo de Samyda nitida L. e foi incluído na tribo Casearieae. Além de ser bem representado na flora brasileira, este gênero destaca-se por sua importância econômica. São plantas com uso medicinal (Siqueira 1981, 1988), utilizadas como depurativas

Artigo recebido em 02/2006. Aceito para publicação em 02/2007.

${ }^{1}$ Parte da Dissertação de Mestrado do primeiro autor desenvolvida na ENBT/JBRJ.

${ }^{2}$ Instituto Brasileiro de Geografia e Estatística/Pesquisadores do Convênio IBGE/JBRJ, no Instituto de Pesquisas Jardim Botânico do Rio de Janeiro.

${ }^{3}$ Correspondência: Rua Pacheco Leão 915, 22460-030, Rio de Janeiro-RJ, Brasil. rmarquet@jbrj.gov.br 
do sangue e, também, o suco de suas folhas servem para mordeduras de cobras (Torres \& Yamamoto 1986; Borges 1997). Segundo Sanchotene (1989) podem ser utilizadas em logradouros públicos, por apresentarem porte médio e sistema radicular profundo, não afetando as calçadas. Sua madeira tem utilidade comercial, podendo ser utilizada como lenha, construção civil e também trabalhos de marcenaria (Marchiori 1997).

Do ponto de vista da interação plantaanimal, as espécies são dispersas por aves que consomem suas sementes (Sanchotene 1989). Isto provavelmente, explica sua grande dispersão pelo neotrópico. Suas flores apresentam néctar aromático o que atrai uma grande quantidade de visitantes (insetos).

Este trabalho apresenta o estudo do gênero Casearia no estado do Rio de Janeiro, explorando aspectos taxonômicos, morfológicos e a distribuição das espécies nas diferentes formações vegetacionais.

\section{Material e Métodos}

Foram analisados as coleções dos seguintes herbários: G, K, BM, NY, F, P, R, RB, S, A, B, FCAB, GUA, HB, IAC, M, R, RB, RBR, RFA, RFFP, RUSU (Holmgren et al. 1990) e foram realizadas expedições a vários municípios do estado do Rio de Janeiro em diferentes épocas do ano. Além do material para herborização, flores e frutos foram conservados em álcool $70 \%$ com glicerina para observação, descrição morfológica e ilustração de suas estruturas.

Os desenhos de macromorfologia foram realizados em microscópio Carl Zeiss (equipado com câmara clara) em diferentes escalas de aumento. Para observação morfológica externa foram utilizados os conceitos de Lawrence (1951), Rizzini (1977) e Stearn (1983).

Os pontos de coleta foram plotados em mapas do estado do Rio de Janeiro cedidos pelo Programa Mata Atlântica do Jardim Botânico do Rio de Janeiro, utilizando-se a localização geográfica fornecida pelo sítio do IBGE: www.ibge.gov.br/cidades/sat/. Para as formações vegetacionais e para as legendas usadas no quadro de distribuição geográfica foram utilizados os conceitos de Veloso et al. (1991).

\section{Resultados e Discussão \\ Tratamento Taxonômico}

Casearia Jacq., Enum. Syst. Pl. 4:21.1760; Select. Stirp. Amer. Hist. 132, t.85. 1763; Eichler in C.P. von Martius, Fl. bras. 13(1): 457. 1871; Gilg in Engler \& Prantl, Nat. Pflazenfam. ed. 2, 21: 451. 1925; Sleumer, Fl. Neotrópica 22: 280. 1980.

Espécie tipo: Casearia nitida (L.) Jacq. Árvores, arbustos ou subarbustos, tronco de casca lisa a fissurada; ramos cilíndricos, patentes, levemente flexuosos a eretos, cor acinzentada ou amarronzada; estípulas ovadas a subuladas, caducas ou persistentes; folhas dísticas, alternas, com ou sem pontos e traços translúcidos, pecíolo subcilíndrico a cilíndrico ou canaliculado; inflorescências axilares, fasciculadas ou em glomérulos, multifloras ou paucifloras; flores hermafroditas, pequenas, pedicelos não articulados a articulados acima da base, esverdeadas, sépalas 5, livres ou soldadas na base, reflexas na antese, estames 8-10, unisseriados, perigíneos, filetes filiformes ou cilíndricos, conatos ao disco na base, anteras rimosas, oblongas a globosas, geralmente glândulas no ápice, lobos do disco claviformes, geralmente alternos aos estames, ovário súpero, unilocular, tricarpelar, placentação parietal, óvulos poucos a numerosos, estilete inteiro ou trífido no ápice, estigma simples ou trilobado no ápice, globoso ou capitado; fruto cápsula, globosa, obovada a obovado-oblonga, trivalvar, sépalas persistentes.

Este gênero distribui-se nas regiões tropicais de todo o mundo, possuindo cerca de 180 espécies (Sleumer 1980). No Brasil, encontramos cerca de 45 espécies, sendo 19 restritas ao território brasileiro e 25 com ampla distribuição. No estado do Rio de Janeiro encontramos 12 espécies. 


\section{Chave para identificação das espécies de Casearia no Rio de Janeiro}

1. Inflorescências em glomérulos.

2. Lâminas foliares coriáceas; inflorescências multifloras, flores pediceladas, estilete tripartido C. selloana

2'. Lâminas foliares membranáceas; inflorescências paucifloras, flores sésseis a subsésseis, estilete inteiro

C. sessiliflora

1'. Inflorescências em fascículos.

3. Inflorescências pedunculadas a curto-pedunculadas.

4. Flores com estilete inteiro

C. arborea

4'. Flores com estilete tripartido ou trífido.

5. Ramos densamente lenticelados; lâmina glabra, ápice da lâmina agudo, subacuminado a levemente obtuso, pontos e traços translúcidos dispersos na lâmina; sementes vilosas, arilo fibroso glabro C. luetzelburgii

5'. Ramos esparsamente lenticelados; lâmina levemente puberulenta na nervura primária a glabrescente, ápice da lâmina longo-acuminado a falcado, pontos e traços translúcidos densamente dispersos na lâmina, mais densos nos bordos; semente esparsamente hirsuta, arilo fibroso com indumento viloso C. obliqua

3'. Inflorescências sésseis.

6. Folhas coriáceas, lâmina glabra ou levemente pilosa na nervura primária.

7. Ápice da lâmina largamente acuminado a atenuado; anteras com glândula apical

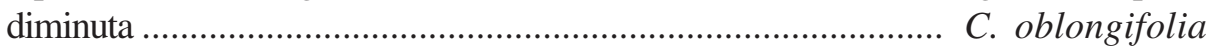

7'. Ápice da lâmina acuminado, agudo a curtamente acuminado; antera sem glândula apical.

8. Lâmina com pontos e traços translúcidos não visíveis a olho nu; lobos do disco entre os filetes e o ovário; estilete trífido, esparsamente piloso

C. commersoniana

8'. Lâmina com pontos e traços translúcidos dispersos (mais visíveis nos bordos da lâmina); lobos do disco intercalados com os filetes; estilete inteiro, esparsamente pubescente

C. melliodora

6'. Folhas cartáceas ou membranáceas, lâmina glabra ou vilosa, raramente pubescente na nervura primária.

9. Lâmina membranácea; ovário glabro, estigma trilobado

C. sylvestris

9'. Lâmina cartácea; ovário piloso, estigma inteiro.

10. Lâmina vilosa em ambas as faces; botões vilosos; ovário parcialmente piloso, até a metade superior

C. lasiophylla

10'. Lâmina glabra ou com indumento hirsuto-velutino sobre as nervuras ou raramente, pubescente sobre a nervura principal a glabrescente; botões tomentosos; ovário totalmente viloso a híspido-viloso.

11. Base da lâmina cuneada a levemente assimétrica; brácteas glabras; filetes com base tomentosa, estilete esparsamente viloso

C. decandra

11'. Base da lâmina atenuada; brácteas pilosas; filetes glabros, estilete glabro C. pauciflora 
1. Casearia arborea (Rich.) Urb., Symb. Antill. 4(3): 421. 1910.

Figs. 1, 13a

Árvore (3-)5-14(-15) m alt., tronco com casca lisa a levemente estriada, marrom externamente, amarela internamente; ramos inermes, delgados, flexuosos, velutinos no ápice, glabrescente na base, marrons, esparsamente lenticelados; estípulas 4-6 x 0,5-1 mm, lineares a estreitamente ovadas, caducas; velutinas. Folhas persistentes, pecíolo 2-6×1-1,5 mm, cilíndrico, velutino, delgado, lâmina 4-11×1,6$2,9 \mathrm{~cm}$, cartácea, discolor verde, oblongolanceolada a oblongo-elíptica, tomentosa em ambas as faces, mais densa abaxialmente, ápice acuminado com ponta agudamente rostrada, base arredondada-cuneada levemente atenuada, bordos serreados com dentes curtos, pontos e traços translúcidos dispersos na lâmina, 58(-10) pares de nervuras secundárias ascendentes, reticulado das veias e vênulas denso, mais proeminentes na face abaxial. Inflorescências fasciculadas, multifloras, denso-tomentosas, pedunculadas, $2-4 \mathrm{~mm}$ compr.; brácteas e bractéolas diminutas e livres na base dos pedicelos, subuladas, tomentosas; pedicelos ca. $3 \mathrm{~mm}$ compr., cilíndricos e delgados, articulados no terço inferior, densotomentosos; botões globosos a alongados, tomentosos; sépalas 3-4×1,5-2 mm, soldadas na base, ovadas, esverdeadas, externamente tomentosas e internamente com tricomas adpressos, alvacentos em ambas as faces; estames 10, filetes ca. $2 \mathrm{~mm}$ compr., livres, velutinos na base, anteras ovóides, glândula apical arredondada no dorso; lobos do disco ca. 1,5 mm compr., clavados, densamente velutinos no ápice e glabrescentes na base, soldados na base e alternados com os filetes; ovário oblongo-ovado, glabro; estilete inteiro, espesso, densamente piloso na inserção do ovário e glabrescente para o ápice; estilete inteiro, estigma inteiro, capitado a levemente globoso, tricomas hirsutos. Fruto $7 \times 3,5 \mathrm{~mm}$, imaturo ovóide, glabro, vinoso-esverdeado, sementes $2 \times 1,5 \mathrm{~mm}$, oblongas, testa foveolada (escrobiculadas), arilo franjado, amarelado, cobrindo parcialmente a semente.
Nome vulgar: imbiú amarelo, canela, Material selecionado: BRASIL. RIO DE JANEIRO: Cachoeira de Macacu, INCRA, 16.XI.1983, fl. e fr., M. C. Vianna et al. 1631 (GUA); Duas Barras, Faz. Juca Monerat, 13.XII.1988, bt., J. P. P. Carauta et al. 5689 (GUA); Duque de Caxias, Reserva da Petrobrás, 17.X.2001, bt., S. J. Silva Neto et al. 1497 (RB); Macaé, Pico do Frade de Macaé, 22.X.1985, bt., M. Leitman et al. 25 (RB); Magé/Cachoeira de Macacu, Estação Ecológica Estadual de Paraíso, 16.VII.1992, bt. e fr., C. M. Vieira et al. 227 (RB); Mangaratiba, Ilha de Marambaia, 20.III.2001, bt. e fl., L. F. T. Menezes 806 (RBR); Nova Friburgo, ign., 21.XI.1881, bt. e fl., A. F. M. Glaziou 13404 (R); Petrópolis, Retiro, XI.1943, bt., O. C. Góes \& E. Dionísio 713 (RB); Piraí, Represa de Ribeirão das Lages, 5.I.1989, est., M. R. Barbosa s.n. (RBR 6909); Rio de Janeiro, Tijuca-Corcovado, X.1836, fl., Sello 240 (R); Corcovado, 8.X.1865, fl., A. F. M. Glaziou 845 (R); Rio das Ostras, REBIO União, 27.IX.200, bt. e fl., J. M .A. Braga 6304 (RB); São José do Vale do Rio Preto, Fazenda Belém, 1.VIII.2000, bt. e fl., $F$. M. B. Pereira 29/24 (RFA); Silva Jardim, REBIO de Poço das Antas, 5.II.1993, bt., A. Piratininga et al. 26 (RB); Teresópolis, Serra dos Órgãos, 20.X.1974, bt.,fl. e fr., P. Occhioni 6374 (RFA); Valença, Barão de Juparanã, 9.V.2000, bt. e fl., M. L. C. V. Spolidoro et al. 107 (RB); Varre-Sai, 8.VII.2004, bt., $R$. Marquete et al. 3503 (RB).

Distribuição geográfica e habitat: desde a Guatemala até a Bolívia e Brasil: AM, RR, RO, PA, AP, MG, GO, MA, CE, PE, BA, MG, ES, RJ e SP. Encontrada em vegetação secundária em áreas de floresta ombrófila densa de terras baixas, na borda alterada sobre monte mamelonar em planície quaternária; floresta ombrófila densa baixo montana; floresta ombrófila densa submontana; floresta estacional semidecídual montana; floresta de galeria, floresta semidecídual em transição para savana ou campo. Pode ocorrer desde baixas altitudes até cerca de $1600 \mathrm{~m}$. No estado do Rio de Janeiro, $C$. arborea ocorre com maior frequiência em vegetação de floresta ombrófila densa e floresta estacional semidecídual com variação altitudinal e na composição do solo, sendo mais encontrada no interior da floresta. Espécie heliófila ou de luz difusa.

Dados fenológicos: botões e flores de abril até dezembro, podendo chegar a janeiro. Fruto 


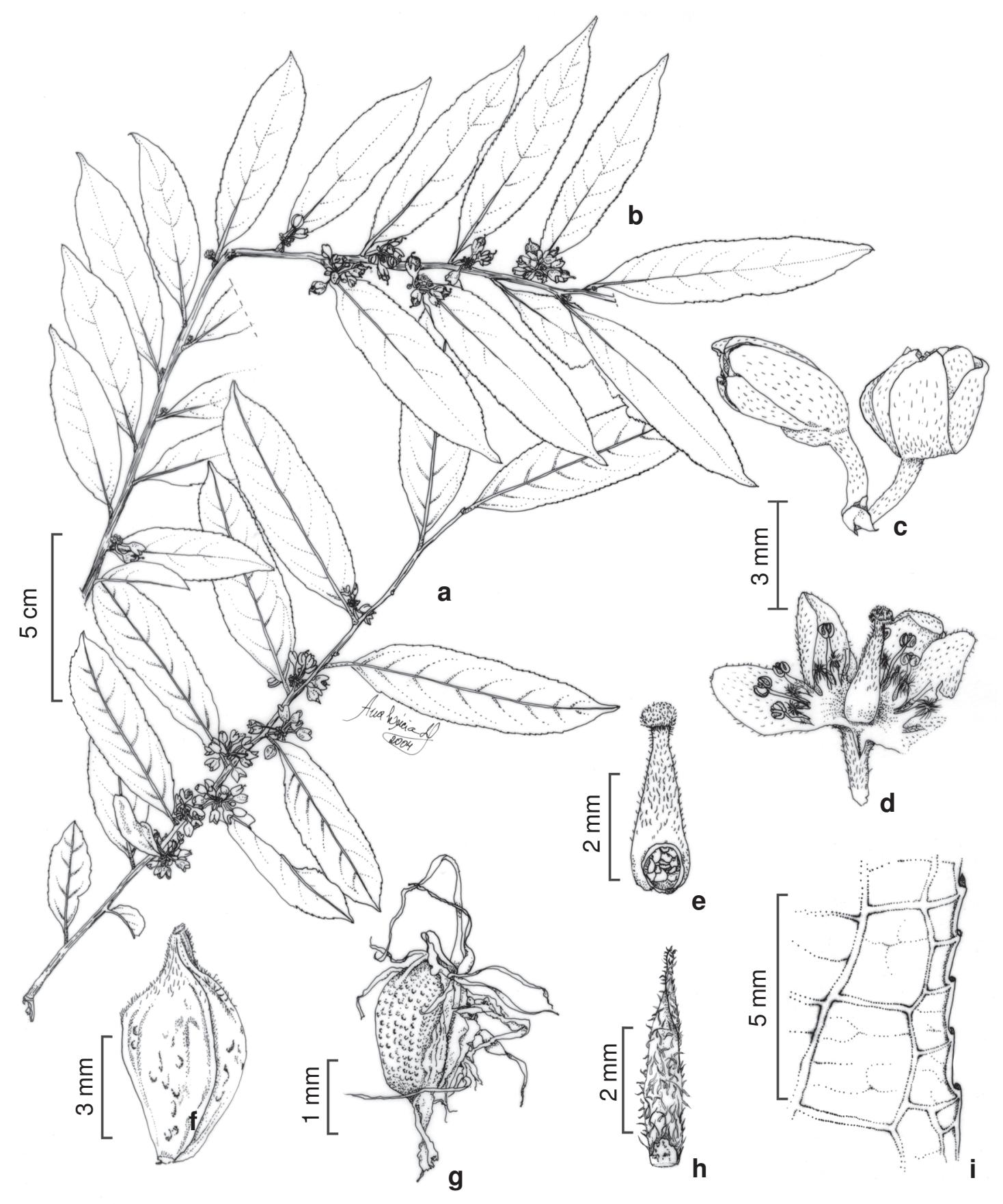

Figura 1- Casearia arborea - a. ramo com botão e flores; b. ramo com flores e frutos; c. botões florais; d. flor aberta; e. gineceu com corte longitudinal do ovário; f. fruto; g. semente com testa escrobiculada e arilo franjado; h. estípula; i. detalhe da margem foliar. (a-e, i Marquete 2970; f, g Marquete 3453; h Marquete 3457) 
imaturo nos meses de janeiro, julho, setembro e outubro.

As árvores observadas apresentavam-se com o tronco único que se ramifica no ápice ou em alguns casos, dividido deste a base em quatro ou em três troncos que se separam do principal a ca. $3 \mathrm{~m}$ de sua altura.

Casearia arborea é próxima de $C$. ulmifolia Vahl ex Ventenat pelo hábito, separando-se tenuemente pela pilosidade e bordo das folhas. Sleumer (1980) menciona que existem formas intermediárias, que às vezes são difíceis de serem separadas. O mesmo é considerado para $C$. grandiflora Cambess., que quando estéril ou em botão, pode ser confundida com C. arborea. Torres \& Yamamoto (1986), estudando as espécies do estado de São Paulo, concordaram com Sleumer (1980) quanto ao material vegetativo, mas as separaram principalmente pela inflorescência, flor e bractéolas, quando fértil.

2. Casearia commersoniana Cambess. in Saint-Hilaire, Fl. Bras. Merid. 2: 235. 1829.

Figs. 2, 13b

Arvoreta ou arbusto 1,5-8 $\mathrm{m}$ alt., tronco com casca lisa a levemente estriada, cor amarronzada a cinza, subcorticosa; ramos inermes, superiores com a base glabra a levemente pilosos no ápice, acinzentados, esparsamente lenticelados; estípulas 2-5,5 × $1 \mathrm{~mm}$, linear-lanceoladas a subuladas, caducas; tomentosas. Folhas persistentes; pecíolo 3-7 mm compr., glabro a levemente piloso em alguns exemplares, espesso; lâmina 7-14,4 × 3-6 cm, coriácea, quando jovem cartácea, discolor verde, às vezes pouco distinguível nesta tonalidade, nítida adaxialmente, obovado-oblonga, cuneadolanceolada a largamente lanceolada, glabra; ápice agudo a curtamente acuminado; base obtusa a cuneada; bordos espaçadamente serrados; traços e pontuações não visíveis contra a luz, 3-5 pares de nervuras secundárias ascendentes, reticulado das veias e vênulas densos, mais proeminente na face abaxial. Inflorescências fasciculadas, 6-11 flores ou mais, sésseis, tomentosas, alvo-esverdeadas; brácteas e bractéolas $2 \times 2,5 \mathrm{~mm}$, ovadas, esparsamente velutinas, pedicelos 4-5 mm compr., cilíndricos, delgados, articulados próximo a base, tomentosos; botões subglobosos, tomentosos; sépalas 2-5 × 2-2,5 mm, livres, ovadas, alvo-esverdeadas, tomentosas; estames 10, livres, alvo-esverdeados e externos ao disco; filetes 4-5 mm compr., levemente alargados na base, glabros, anteras oblongas, sem glândula apical; lobos do disco 1,5 mm compr., oblongo-clavados, intermediários entre os filetes e o ovário, alvo-amarelados, densamente pilosos no ápice e glabrescentes para base; ovário levemente ovado a subgloboso, densamente piloso; estilete cilíndrico, tripartido no ápice, esparsamente piloso, estigmas capitados. Fruto $7-10(-14) \times$ 5(-9) mm, subovado, levemente oblongo a elíptico, imaturo verde, maduro negro a avermelhado, esparsamente piloso; sementes 2 (-6)-3 mm, esféricas a obovadas, amarelo-avermelhadas; arilo carnoso, alvo.

Nome vulgar: sapucainha

Material selecionado: BRASIL. RIO DE JANEIRO: Angra dos Reis, Rebio Estadual da Praia do Sul, 14.V.1985, bt. e fl., R. Ribeiro 628(GUA); Bom Jesus do Itabapoana, cachoeira da Fumaça, 21.VIII.1982, fl., C. M. Rizzini 150 (GUA,RFA); Cachoeiras de Macacu, fazenda do Matão, 18.IV.2000, bt. e fl., $F$. M. B. Pereira 261 (RFA); Cantagalo, 8.XII.1979, fl., L. E. Mello-Filho 5269 (R); Duque de Caxias, 5.VII.1938, bt., A. Passarelli 125 (R); Guapimirim, fazenda Consorciadas, 19.VIII.2000, fl. e fr., F. M. B. Pereira 07/29 (RFA); Itaguaí, Coroa Grande, 26.VI.1957, bt. e fl., A. P. Duarte 4461 (RB); Macaé, distrito de Frade, 5.VI.2000, bt. e fl., M. G. Bovini et al. 1844. (RB,RUSU); Magé/Cachoeiras de Macacu, Estação Ecológica Estadual de Paraíso, 16.X.1984, fr., H. C. Lima et al. 2196 (RB); Mangaratiba, Ilha de Marambaia, 5.I.1986, fl. e fr., E. M. Occhioni 487 (RFA,RUSU); Niterói, 20.VIII.1936, bt. e fl., L. Xavier s.n. (RBR 6933); Nova Friburgo, 1.XII.1935, fr., B. Lutz 985 (R); Paracambi, fazenda do Sr. Antonio Moura, 21.VI.1988, bt., D. F. Lima et al. 79 (GUA); Petrópolis, estrada RioPetrópolis, 27.IV.1938, est., H. Monteiro-Filho 1847 (RBR); Piraí, Represa de Ribeirão das Lages, 17.IV.1991, bt., I. M. Silva 34b (RBR); Rio de Janeiro, ign. s.d., fl. e fr., A. St. Hilaire C 2, n. 45 (Holótipo P, foto F 34894); Corcovado, 15.IX.1867, fl. e fr., $A$. 


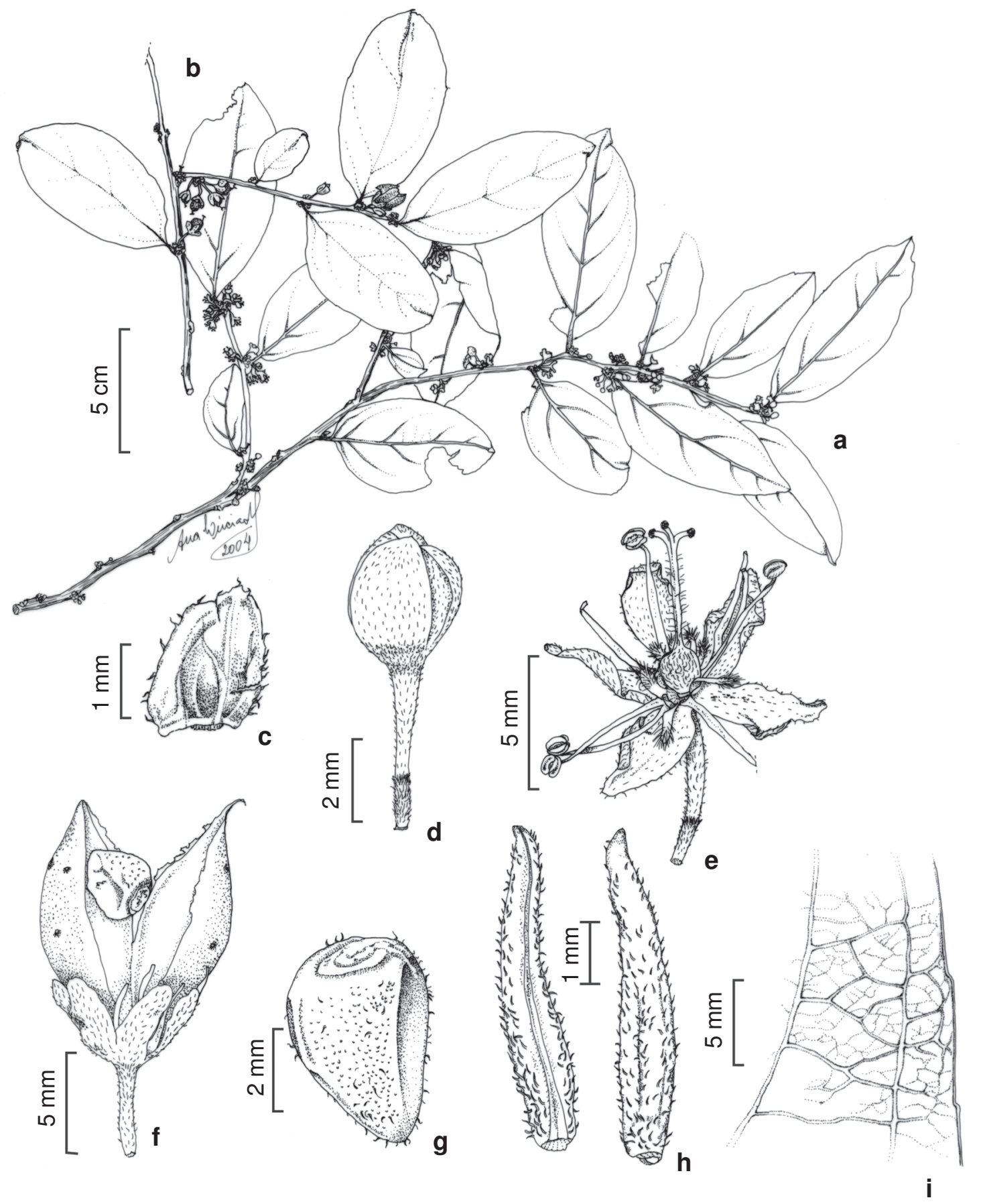

Figura 2 - Casearia commersoniana - a. ramo em botão e flores; b. ramo com frutos jovens e maduros; c. bráctea; d. botão floral; e. flor aberta; f. fruto aberto; g. semente; h. estípulas (ambas as faces); i. detalhe da margem foliar. (a,ce, i Brade 18563; b, f, g Marquete 1991; h Peixoto 33). 
F. M. Glaziou 1507 (R); Seropédica, Itaguaí, 25.XI.1941, fr., L. Barroso \& H. Monteiro-Filho 2425 (RBR); Silva Jardim, REBIO Poço das Antas, 16.VI.1994, bt., D. S. Faria et al. 258 (RB); Teresópolis, Serra dos Órgãos, I.1976, bt., $P$. Occhioni 7875 (RFA).

Distribuição geográfica e habitat: do México até o Brasil: AM, RR, PA AP, MT, MA, PI, PE, AL, BA, MG, ES e RJ. Vegetação secundária, floresta ombrófila densa submontana ou de terras baixas degradadas, floresta ciliar, floresta de galeria, floresta semidecídual, floresta de transição com savana arbórea, savana (cerrado), savana estépica (caatinga), vegetação com influência marinha (restinga): em beira de moita, ilhas de vegetação ou em floresta. No estado do Rio de Janeiro, Casearia commersoniana ocorre com maior frequiência em vegetação de floresta ombrófila densa e apresenta poucos representantes em floresta estacional semidecidual e vegetação de influência marinha. Apresenta uma variação altitudinal e na composição do solo, mas ocorre também em área degradada, geralmente em locais íngremes. Espécie de luz difusa, não atingindo o dossel da floresta.

Dados fenológicos: botões e flores são encontrados de janeiro a novembro e frutos imaturos e maduros são mais colecionados nos meses de julho a outubro.

Sleumer (1980) considerou Casearia commersoniana, C. javitensis H.B.K. $e C$. spruceana Benth. ex Eichler, como espécies próximas, separando-as somente por poucos caracteres florais e frutíferos. Vegetativamente estes três táxons são muito difícies de serem separados. Já Olson et al. (1999) trabalhou essas espécies e separou-as com detalhes de flores e frutos, mas confrontando as chaves observamos, que este confundiu as características de $C$. commersoniana com $C$. spruceana, no que concerne, principalmente ao número de estames.

No material examinado, os frutos de $C$. commersoniana apresentam apenas uma semente desenvolvida e as outras atrofiadas. No campo, observou-se que a maioria dos indivíduos colecionados tinha tronco bifurcado desde a base e, na maioria das vezes, se encontravam em terreno de encosta levemente íngreme e muito visitadas por formigas na antese.

3. Casearia decandra Jacq., En. Pl. Carib. 21. 1760 .

Figs. 3, 13c

Árvore (3-)8-18(-20) m alt.; tronco com casca lisa, cor acinzentada; ramos inermes, eretos, base glabrescente, ápice puberulento, marrom-acinzentada, esparsamente lenticelados; estípulas $7 \times 0,5 \mathrm{~mm}$, subuladas, esparsamente pubescentes no ápice, emergências glandulares nos bordos, caducas. Folhas parcialmente decíduas na floração; pecíolo 2-5 mm compr., subcilíndrico, puberulento, delgado; lâmina 5-7(-9) ×2-4,1 cm, cartácea (quando jovem membranácea), discolor verde, raramente pubescente na nervura primária a glabrescente, lanceolada a oblongo-lanceolada; ápice longo acuminado a acuminado; base cuneada a levemente assimétrica; bordos serreados a crenados com dentes de $0,5 \mathrm{~mm}$, levemente revolutos, poucos dentes na base; pontos e traços dispersos na lâmina, 4-6(-7) pares de nervuras secundárias ascendentes, reticulado das veias e vênulas laxos, pouco proeminente em ambas as faces. Inflorescências fasciculadas, 4-8 flores, fortemente aromáticas, tomentosas, sésseis; brácteas e bractéolas 1-1,5×1 mm, coriáceas, ovadas a escamosas (conchiformes), bractéolas na base do pedicelo, glabras, pedicelos ca. $4 \mathrm{~mm}$ compr., cilíndricos, articulados na base, laxamente tomentosos. Botões obovado-oblongos a oblongo-ovados, tomentosos, sépalas ca. $3 \times 1 \mathrm{~mm}$, curtamente soldadas na base, oblongo-lanceoladas, esverdeadas, externamente laxo-tomentosas; estames 10 , filetes $1(-2,5) \mathrm{mm}$ compr., livres, base tomentosa, glabro para o ápice, anteras globosas, sem glândulas apicais (amarelas quando secas), lobos do disco 0,5 mm compr., oblongo-clavados, soldados na base, alternos com os filetes, amarelos quando secos, tomentosos, ovário ovado a oblongo-ovado, 


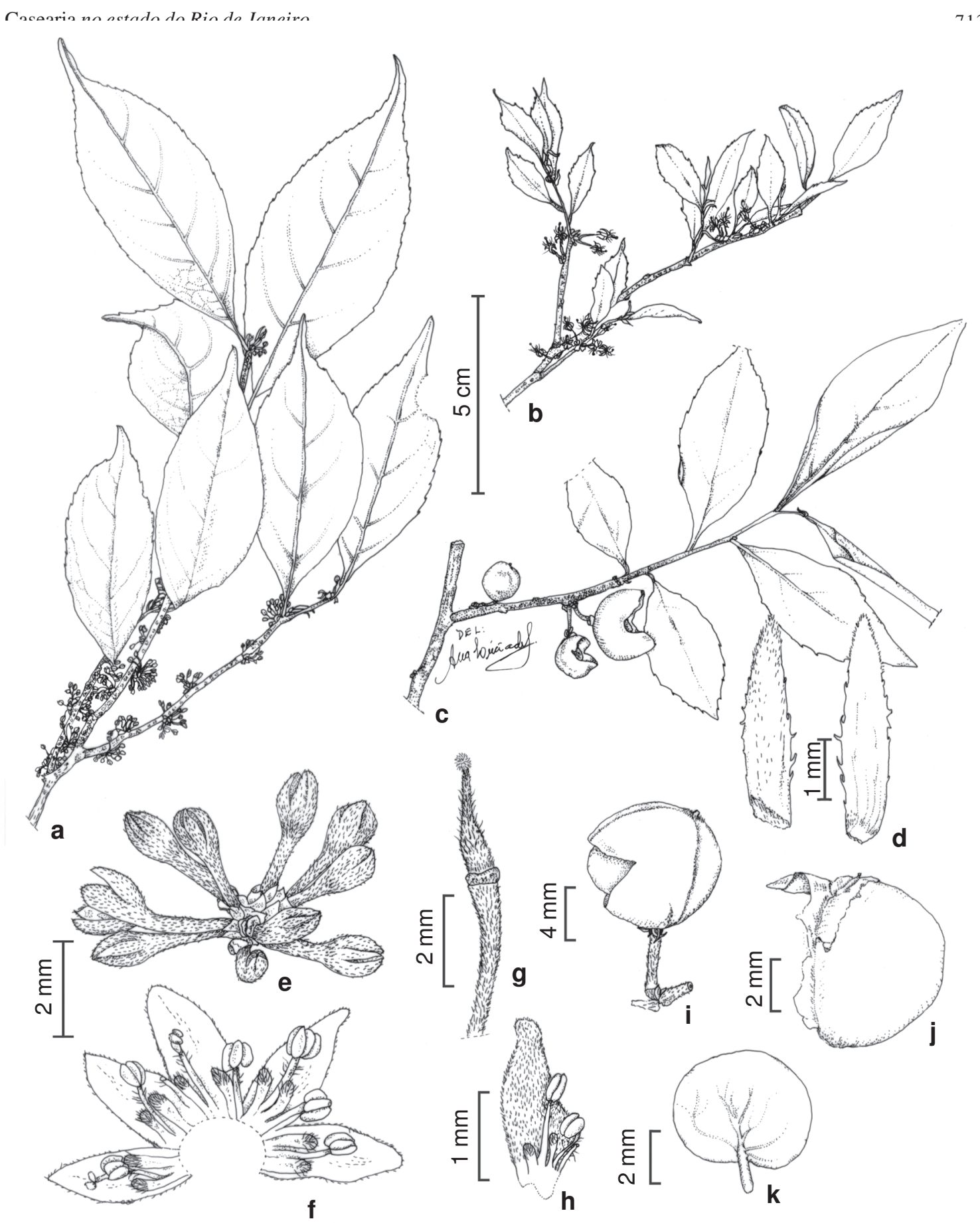

Figura 3 - Casearia decandra - a. ramo com inflorescência em botão; b. ramo em flor com folhas jovens; c. ramo com frutos; d. estípulas (ambas as faces); e. inflorescência em botões; f. flor aberta; g. gineceu; h. detalhe da sépala com lobos do disco intercalados com os filetes; i. fruto; j. semente com arilo; k. embrião reto. (c,i-k Marquete 281; a, e Marquete 3377; b, d, f-h Vieira 433) 
viloso; estilete inteiro, delgado, esparsamente viloso, estigma inteiro, capitado, piloso. Fruto 1,3-1,5 × 1,3-1,5 cm, imaturo verde, maduro amarelo a vinoso, globoso, indumento próximo ao estilete vestigial e na base junto às sépalas, sementes $3-5,7 \times 6,5 \mathrm{~mm}$, poliédricas, testa lisa, arilo amarelo, delgado, cobrindo parcialmente a semente, sendo mais crasso na parte reta; embrião 5,5-7,5 ×5,5-6,5 mm, reto, amarelo, cotilédones foliáceos, arredondados a cordados junto ao eixo.

Nome vulgar: anavinga (SP)

Material selecionado: BRASIL. RIO DE JANEIRO: Campos dos Goytacazes, 20.IX.2000, fl., J. M. A. Braga \& G.R. Rabelo 6248 (RB); Itatiaia, 1918, $P$. C. Porto s.n. (RB 10599); Mendes, Fazenda São José das Paineiras, 11.IX.1993, bt. e fl., J. M. A. Braga 631 (RUSU); Nova Friburgo, Ginásio Anchieta, 1.XII.1953, J.G. Kuhlmann s.n. (RB 102307); Petrópolis, Itaipava, 14.IX.1946, P. Danserean s.n. (RB 58143); Piraí, Represa do Ribeirão da Lages, 5.X.1988, est., M. R. Barbosa s.n. (RBR 6918); Rio de Janeiro, Corcovado, 12.IX.1872, bt. e fl., A. F. M. Glaziou 6198 (R); Saquarema, 22.VIII.1986, fl., C. Farney \& M. Nadruz 1162 (GUA); Teresópolis, 25.VIII.2002, bt. e fl., R. Marquete et al. 3377 (RB). Material adicional: MARTINICA: circa vicum Case Pilote, IV.1755, fl., J.F. Jacquin s.n. (holótipo BM!). Distribuição geográfica e habitat: América Central, América do Sul: Colômbia, Venezuela, Trindade, Guiana, Suriname, Guiana Francesa, Equador, Peru, Paraguai, Uruguai, Argentina e Brasil: AM, RR, MT, GO, DF, PE, MG, SP, RJ, PR, SC e RS. Ocorre em floresta seca de planície, floresta ombrófila densa e flombrófila densa montana de encosta degradada. No estado do Rio de Janeiro, Casearia decandra ocorre com maior frequiência em vegetação de floresta ombrófila densa da Serra do Mar e com pouca representatividade em vegetação de influência marinha. Ocorre em diferentes altitudes e tipos de solo, em ambiente de luz difusa e, ocasionalmente, atingindo o dossel da floresta.

Dados fenológicos: botões e flores em maio, agosto a outubro; frutos nos meses de outubro a dezembro.

Esta espécie ocorre próxima a rios e córregos, apresenta caducifolia na floração e flores aromáticas. Os exemplares examinados apresentaram apenas uma semente dentro da cápsula. Segundo Kuhlmann \& Kuhn (1947), as flores são muito visitadas por abelhas e outros insetos e os frutos fazem parte da dieta dos macacos (guaribas), o que se confirmou no exame das amostras dos seus escrementos.

4 - Casearia lasiophylla Eichler in Mart. \& Eichler, Fl. bras. 13(1): 468, t. 94. 1871.

Figs. $4,13 \mathrm{~d}$

Arbusto a árvore pequena 2,5 a $3 \mathrm{~m}$ alt.; ramos inermes, levemente estriados, glabros na base, pilosos para o ápice, marrons, denso-lenticelados; estípulas $5 \times 1 \mathrm{~mm}$, estreitamente lanceoladas a subuladas, persitentes nos ramos jovens, vilosas, caducas. Folhas com caducifolia na floração; pecíolo 4-6 mm compr., semicilíndrico, viloso; lâmina 6-11(-15) ×2-4,5 cm, cartácea, discolor verde, lanceolada, oblongo-lanceolada, vilosa em ambas as faces, sendo mais densa na face abaxial; ápice agudo a acuminado; base cuneada a levemente assimétrica; bordos esparsamente serrados; pontos translúcidos poucos e esparsos na lâmina, 5-8 pares de nervuras secundários ascendentes, reticulado das veias e vênulas denso, oculto pelos tricomas, mais proeminente na face abaxial. Inflorescências fasciculadas, multifloras, sésseis, tomentosas; brácteas 1-1,5 mm compr., ovadas a arredondadas envolvendo o pedicelo, glabras a parcialmente pilosas; pedicelos 4-7 mm, cilíndricos, articulados próximos à base, pilosos. Botões globosos a oblongos, vilosos; sépalas 5-6 × 1-1,5 mm, soldadas próximo à base, ovadas a subuladas, esverdeadas, vilosas em ambas as faces; estames 10 , filetes $1,5 \mathrm{~mm}$ compr., cilíndricos, pilosos na base, estames e discos soldados e adnatos na base das sépalas; anteras oblongas a oblongo-globosas, sem glândula apical; lobos do disco 1-2,5 mm compr., clavados, soldados na base e alternos com os filetes, alvoesverdeado, vilosos; ovário ovado, piloso até a metade superior; estilete inteiro, delgado, piloso; estigma inteiro, capitado, glabro. Fruto 6-10 


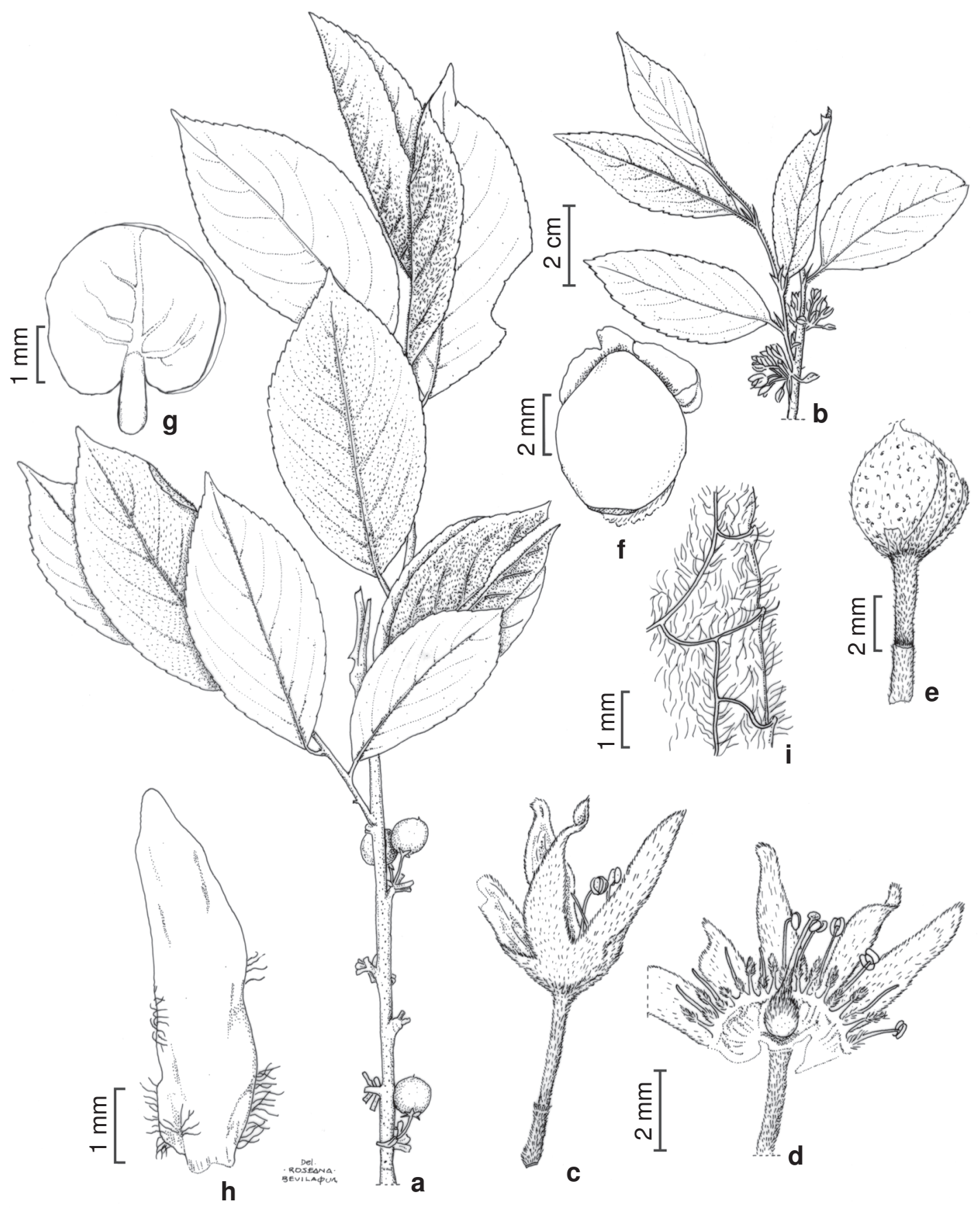

Figura 4 - Casearia lasiophylla - a. ramo com frutos; b. ramo com flores; c. flor; d. flor aberta, mostrando gineceu e androceu intercalados com os lobos do disco; e. fruto; f. semente com arilo; g. embrião reto; h. estípula; i. cerdas no bordo da lâmina. (c, d, h, i Duarte 8447, b, g Regnell III-393; a, e Sello s.n. - P) 
$\times 7-10 \mathrm{~mm}$, globoso, esparsamente piloso, negro quando seco, sementes poucas, $6 \times 5$ $\mathrm{mm}$, ovóides, testa lisa, alaranjada, arilo carnoso, alaranjado, endosperma carnoso, alaranjado, embrião reto, $5 \times 4 \mathrm{~mm}$, alaranjado, cotilédones crassos, base cordada.

Material selecionado: BRASIL. RIO DE JANEIRO: Itatiaia, lote 31, 24.IX.1918, bt. e fl., P. C. Porto 740 (RB); Nova Friburgo, Sítio do Gaúcho, X.1964, fl., A. P. Duarte \& E. Pereira 8447 (RB); Rio de Janeiro, Floresta da Tijuca, 4.II.1868, fl., A. F. M. Glaziou $2896 a(\mathrm{R})$.

Material adicional: BRASIL. ign. s.d, fl., L. Riedel s.n. (síntipo P!). MINAS GERAIS: ign., s.d., fl., $P$. Claussen 624 (síntipo BM!, foto RB!); Caldas, 121864, fr., A. F. Regnell III. 393 (síntipo P!); Morro Velho, IX.1840, fl., J. S. Gardner 4494 (síntipo BM!). SÃO PAULO, s.d., fr., F. Sello 5237 (isolectótipo $\mathrm{P}$ !, foto $\mathrm{F}$ !).

Distribuição geográfica e habitat: Brasil: PI, AL, MG, RJ, SPe SC (Sleumer, 1980). Floresta ombrófila mista; savana; floresta ombrófila densa montana, acima de 1100 metros. No estado do Rio de Janeiro, Casearia lasiophylla ocorre em floresta ombrófila densa montana (acima de 500 m s.m.). Espécie de luz difusa, rara heliófila e muito pouco representada nos acervos.

Dados fenológicos: encontrada com botões e flores em fevereiro e setembro a novembro.

Espécie pouco encontrada na natureza. Nas áreas visitadas, onde P. C. Porto e A. P. Duarte haviam coletado este táxon, há 40 anos atrás, não foram localizadas. Talvez esta espécie esteja em perigo de extinção, dada a sua área de distribuição ser coincidente com a área da Mata Atlântica.

5 - Casearia luetzelburgii Sleumer, Notizbl. Bot. Gart. Berlin-Dahlem 11: 995. 1934.

Figs. 5, 13e

Árvore 6-12(-14)m alt.; tronco com casca lisa, castanha; ramos raramente com espinhos, puberulentos, amarronzados, densamente lenticelados, lenticelas arredondadas; estípulas $2 \times 3(-4) \mathrm{mm}$, subuladas, pubescentes, caducas. Folhas persistentes; pecíolo 2-3 $\mathrm{mm}$ compr., pubescente a puberulento, delgado, canaliculado; lâmina 3-6,8 × 1,8-3,5 cm, cartácea (quando jovem membranácea), discolor verde, quando desidratada parda, levemente lanceolada a oblongo-lanceolada, oblongo-ovada, glabra; ápice agudo a subacuminado a levemente obtuso; base levemente atenuada a curtamente agudo-arredondada; bordos serreados com glândulas nos dentes; pontos e traços dispersos na lâmina, raramente com traços no ápice, 79 pares de nervuras secundárias paralelas até próximo à margem, onde tornam-se ascendentes, reticulado das veias e vênulas denso, proeminente em ambas as faces. Inflorescências fasciculadas, paucifloras, pilosas quando jovens a glabrescentes com o tempo, curto pedunculadas; brácteas e bractéolas externas ovadas, conchiformes, coriáceas, internas pequenas e delgadas, diminutas, glabras, quando secas marrons; pedicelos 4-7 $\mathrm{mm}$ compr., cilíndricos, flexuosos, articulados próximo à base, glabros. Botões oblongos, glabros, sépalas ca. $4 \times 2 \mathrm{~mm}$, soldadas na base formando um tubo curto, oblongas a oblongo-elipticas, alvas, glabras; estames 10, filetes 2-3 mm compr., cilíndricos, glabros; anteras oblongas, sem glândulas apicais; lobos do disco ca. 0,5 mm compr., alvos-esverdeados, pilosos no ápice, intercalados com os filetes e adnatos às sépalas; ovário alvo-esverdeado, glabro; estilete pouco espesso, profundamente tripartido, glabro; estigmas capitados, glabros. Fruto 4-8,5 mm compr., coriáceo, ovado a globoso, marrom, glabro; sementes 2-2,5 × $1 \mathrm{~mm}$, vilosas, obovadas a obovado-oblongas, raramente arredondadas, castanhas, curtamente apiculadas, com testa apresentando escrobiculada, arilo fibroso glabro, endosperma carnoso, avermelhado, alongado, embrião reto.

Nome vulgar: pau vidro (BA).

Material selecionado: BRASIL. RIO DE JANEIRO: Niterói/Maricá, Itaipuaçu, Pico do Alto Moirão, 26.VIII.1981, fr., R. H. P.Andreata et al. 94 (RB, RUSU); Rio de Janeiro, Pedra de Guaratiba, 27.XI.2001, est., G. L. Peixoto et al. 78 (RB); São Pedro da Aldeia, Serra de Sapiatiba, 18.VI.2004, est., R. Marquete \& M. Gomes 3474 (RB). 


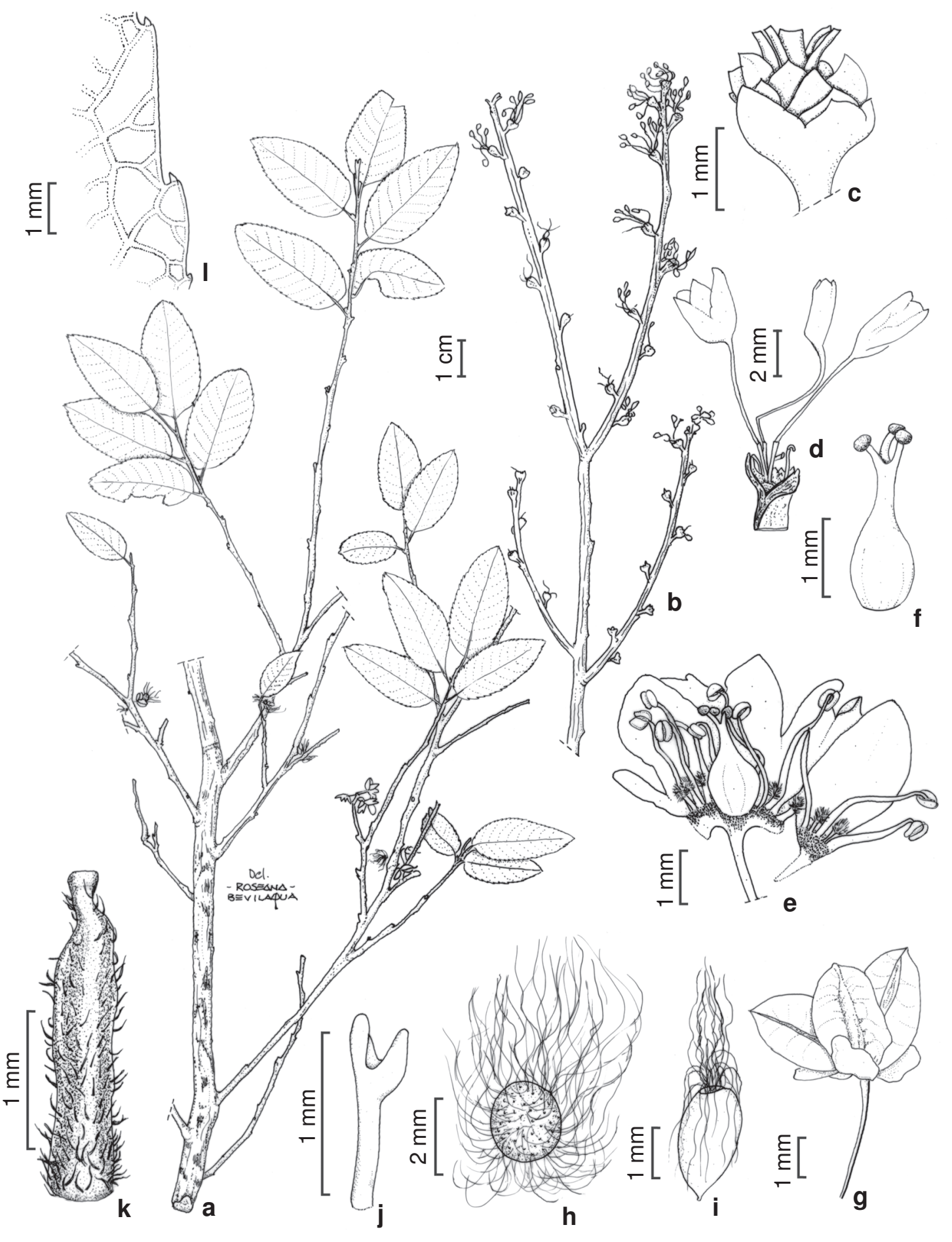

Figura 5 - Casearia luetzelburgii - a. ramo com inflorescências em flores; b. ramo com botões e flores; c. receptáculo com brácteas coriáceas; $d$. receptáculo com pedicelos florais; e. flor aberta, mostrando gineceu e androceu intercalados com os lobos do disco; f. ovário; g. cápsula aberta com sépalas persistentes; h. semente vilosa; i. arilo fibroso; j. embrião reto; k. estípula; 1. cerdas no bordo da lâmina. (a, g, h, j Farney 4160; k Araújo Filho 954; b-f Jesus 1751; i, 1 Andreata 94) 
Distribuição geográfica e habitat: Brasil: $\mathrm{PE}$, BA e RJ. Áreas secas em afloramentos rochosos; floresta estacional semidecidual. No estado do Rio de Janeiro, Casearia luetzelburgii ocorre em floresta estacional semidecidual com afloramentos rochosos, sendo mais encontrada em baixas altitudes. Segundo análise de Ururahy et al. (1983), em São Pedro da Aldeia, na área da Serra de Sapeatiba a vegetação é de savana estépica. O material Farney 4160 (RB) cita o local de coleta como sendo de floresta estacional semidecídual com afloramento rochoso. Os materiais de Andreata 94, 722, 727 (RUSU) de Itaipuaçu, Pico do Alto Mourão, em floresta ombrófila densa degradada de encosta e, Peixoto 78 (RB) para Guaratiba, como floresta ombrófila densa secundária com afloramento rochoso. Notamos que esta espécie se adapta a áreas de vegetação xeromórfica de encosta, nos diferentes tipos de vegetação.

Dados fenológicos: flores em julho e em frutificação em agosto e setembro.

Esta espécie ocorre em áreas secas do nordeste brasileiro, e em sua nova ocorrência para o estado do Rio de Janeiro, em área de floresta estacional semidecídual. Facilmente confundida nos herbários com $C$. gossypiosperma Briquet., que apresenta a forma da folha com o ápice que é sempre longamente acuminado e pecíolo longo, enquanto que em $C$. luetzelburgii, o ápice vária de obtuso a arredondado, além das sementes, que são apiculadas.

6. Casearia melliodora Eichler in Mart. \& Eichler, Fl. bras. 13(1):469. 1871.

Figs. 6, 13f

Árvore (Eichler 1871); ramos inermes, levemente estriados, glabros, acinzentados, densamente lenticelados, lenticelas arredondadas a oblongas; estípulas ca. $5 \times 1 \mathrm{~mm}$, subuladas a linear-lanceoladas, tomentosas em ambas as faces, caducas. Folhas caducas na floração; pecíolo (4-)8-10 mm compr., espessado, glabro; lâmina (10-)13-16 × 4,5-8,6 cm, largamente lanceolada a lanceolada, oblongolanceolada, coriácea, esverdeada a amarelada quando seca, glabra; ápice acuminado; base larga atenuada a levemente assimétrica; bordos inteiros a espaçados, serreados próximo ao ápice, cerdas diminutas, pontos e traços translúcidos dispersos, mais visíveis nos bordos, 5-7 pares de nervuras secundárias largamente ascendentes, reticulado das veias e vênulas laxa, mais proeminente na face abaxial. Inflorescências fasciculadas, multifloras, sésseis, tomentosas; brácteas 1-1,5 mm compr., ovadas, coriáceas, puberulentas, margem mais hialina no terço superior; pedicelos ca. $5 \mathrm{~mm}$ compr., cilíndricos, articulados, ca. $1 \mathrm{~mm}$ da base, tomentosos. Botões oblongos, tomentosos; sépalas $4-5 \times 1,5 \mathrm{~mm}$, curtamente soldadas na base, eretas na antese, linear-oblongas, esverdeadas, tomentosas em ambas as faces; estames 10, filetes ca. $2 \mathrm{~mm}$ compr., subulados, base do filete curto-vilosa, glabrescente para o ápice; anteras subglobosas a oblongas, sem glândula apical; lobos do disco ca. $2 \mathrm{~mm}$ compr., oblongo-clavados, alvo-esverdeados, curto vilosos, soldados na base e intercalados com os filetes; ovário oblongo-ovado, base glabra, do meio para o ápice pubescente, glanduloso, óvulos muitos, estilete inteiro, cilíndrico, mais ou menos espesso, esparsamente pubescente; estigma inteiro, capitado, hirsuto. Fruto não visto.

Material examinado: BRASIL. RIO DE JANEIRO: Rio de Janeiro, Corcovado, s.d., fl., L. Riedel s. $n$., , foto F 13681; isolectótipos: BM!, G!, K!, NY!); Cantagalo, 1916, est., Dr. Souza Brito s.n. (RBR 6914); Itatiaia, 1918, P. C. Porto s.n. (RB 10601); Ibidem, 1918, P. C. Porto s.n. (RB 21432); Ibidem, P. C. Porto 733 (RB); Nova Friburgo, Cascatae Pinel, 26.IX.1953, bt., $P$. Capell S. J. s.n. (FCAB 1305); Santa Maria Madalena, s.d., fl., A. Lisboa s.n. (RB 2722).

Distribuição geográfica e habitat: Brasil: MG e RJ. Floresta ombrófila densa montana, savana. No estado do Rio de Janeiro, Casearia melliodora ocorre em vegetação de floresta ombrófila densa montana, não sendo encontrada até o momento em outro tipo de vegetação. É uma espécie de luz difusa, pouco colecionada. 


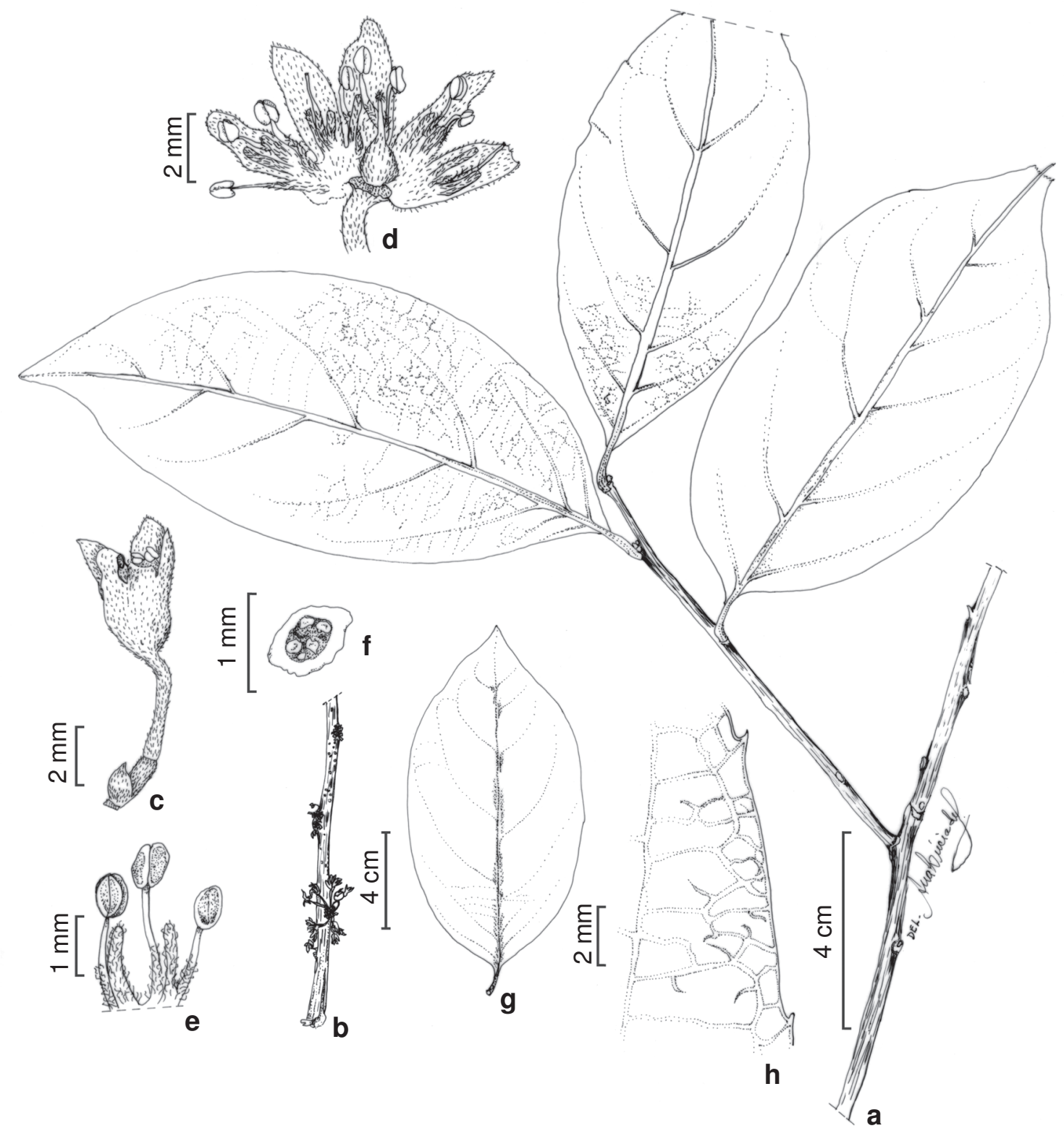

Figura 6 - Casearia melliodora - a. ramo; b. detalhe da inflorescência fasciculada; c. flor; d. flor aberta; e. detalhe dos lobos do disco intercalados com os filetes; f. corte transversal do ovário; g. forma da lâmina face adaxial; h. cerdas no bordo da lâmina. (c-f, h Lisboa s.n. RB 2722; a, b, g Riedel s.n. BM, P) 
Dados fenológicos: Botões em setembro.

Não se tem registro da ocorrência desta espécie na natureza por mais de 50 anos, provavelmente está extinta no estado do Rio de Janeiro.

7. Casearia obliqua Spreng., Syst. veg. 2: 355. 1825.

Figs. $7,14 \mathrm{a}$

Árvore ou arbusto $2-8,7(-11,5) \mathrm{m}$ alt.; tronco com casca lisa, levemente estriada; ramos inermes, flexuosos, base glabra, ápice pubescente, castanho, esparsamente lenticelados, lenticelas arredondadas a oblongas; estípulas ca. $4,8 \times 1 \mathrm{~mm}$, subuladas, tomentosas nas duas faces, caducas. Folhas persistentes; pecíolo 5-10 mm compr., pubescente, cilíndrico; lâmina 5,5-9,6 × 1,8-4 cm, cartácea, discolor, verde, marrons quando secas, lanceolada, lanceolada-ovada, levemente puberulenta na nervura primária a glabrescente; ápice longo-acuminado a falcado; base assimétrica; bordos serreados com glândula no ápice das cerdas; pontos e traços densos na lâmina, nas folhas maiores mais densos nos bordos, 5-6 pares de nervuras secundárias ascendentes, reticulado das veias e vênulas denso, nervuras proeminentes em ambas as faces. Inflorescências fasciculadas, multifloras, curtamente pedunculadas, tomentosas; brácteas e bractéolas ovadas a escamosas (conchiformes), na base do pedicelo, puberulentas; pedicelos 3-5 mm compr., cilíndricos, delgados, articulados a 1-3 mm compr. acima da base, pubescentes. Botões globosos, puberulentos; sépalas ca. $1,5 \times 1 \mathrm{~mm}$, curtamente soldadas na base, oblongolanceoladas, alvo-esverdeadas, puberulentas; estames 10, filetes $1,5 \mathrm{~mm}$ compr., cilíndricos, glabros; anteras oblongas, sem glândula no ápice; lobos do disco clavados (muito mais curtos que os filetes), pilosos, intercalados com os filetes; ovário oblongo-ovado, glabro, estilete trífido no ápice, delgado, cilíndrico, glabro, estigma capitado, reflexo. Fruto 2,5-4 $\times 3 \mathrm{~mm}$, imaturo verde, pedúnculo tomentoso, com glândulas no epicarpo, oblongo a obovadooblongo, glabro; sementes $4,1,5 \times 1 \mathrm{~mm}$, arredondadas a oblongo-elípticas, testa foveolada, amarronzada, esparsamente hirsuta, apículo na base da semente, arilo fibroso com indumento viloso, laranja, endosperma carnoso, laranja, embrião $1 \mathrm{~mm}$ compr., reto, alvo, cotilédones arredondados.

Nome vulgar: erva-de-lagarto; folha-miúda; canela-de-veado; pau-de-espeto.

Material selecionado: BRASIL. RIO DE JANEIRO: Barra Mansa, 16.VI.1987, fl., L. E. Mello Filho 5255 (R); Cabo Frio, Tamoios, 10.XI.2000, bt. e fl., $C$. Farney \& J. C. Gomes 4313 (RB); Itaguaí, 1.I.1959, bt., G. F. J. Pabst 4646 (HB); Itatiaia, 15.VIII.1918, fl., P. C. Porto 684 (RB); lote 82, 11.I.1935, fl., P. C. Porto 2666 (RB); Maricá, Arredores de Marica, III.1934, est., H. Monteiro-Filho 983 (RBR); Niterói/Maricá, Itaipuaçu, Alto Moirão, 20.IX.1989, est., R. H.P. Andreata et al. 914 (RB); Nova Friburgo, Reserva Ecológica Municipal de Macaé de Cima, 20.VII.1990, est., T. Fontoura et al. s.n. (RB 291906); Petrópolis, Bairro Amoedo, XII.1944, fl., O. C. Góes \& E. Dionísio 810 (RB); Piraí, Represa do Ribeirão das Lages, 8.IV.1991, est., A. L. Peixoto et al. 6257 (RBR); Rio de Janeiro, Corcovado, 23.I.1870, bt. e fl., A. F. $M$ Glaziou 4205 (R); São Pedro da Aldeia, Serra de Sapiatiba, 18.VI.2004, est., R. Marquete \& M. Gomes 3476 (RB); Seropédica, Escola Nacional de Agronomia, 25.XI.1941, est., H. Monteiro-Filho \& L. Barroso 2413 (RBR); Teresópolis, PARNA Serra dos Órgãos, 8.III.1956, bt. e fl., E. Pereira 1926 (RB); Valença, Distrito de Barão de Juparanã, 25.VIII.2000, est., M. L. C. V. Spolidoro et al. 277 (RB).

Material adicional: BRASIL. Ign. 1875, bt. e fl., $F$. Sello s.n. (Provável isotipo P!, NY!, BM!).

Distribuição geográfica e habitat: Brasil: BA, MG, ES, RJ, SP, PR e SC. Floresta ombrófila densa, floresta ombrófila mista, floresta estacional semidecídual, vegetação secundária; savana arbórea, vegetação de influência marinha. No estado do Rio de Janeiro, Casearia obliqua ocorre desde próximo ao nível do mar atingindo as serras mais íngremes do estado. Esta espécie é característica de floresta ombrófila densa, onde atinge o dossel e, em áreas abertas, torna-se mais baixa, sendo sempre heliófila; ocorre também em áreas secundárias e afloramentos rochosos. Dados fenológicos: Botões e flores em junho e de outubro a abril. Frutos imaturos em dezembro, janeiro e abril. 


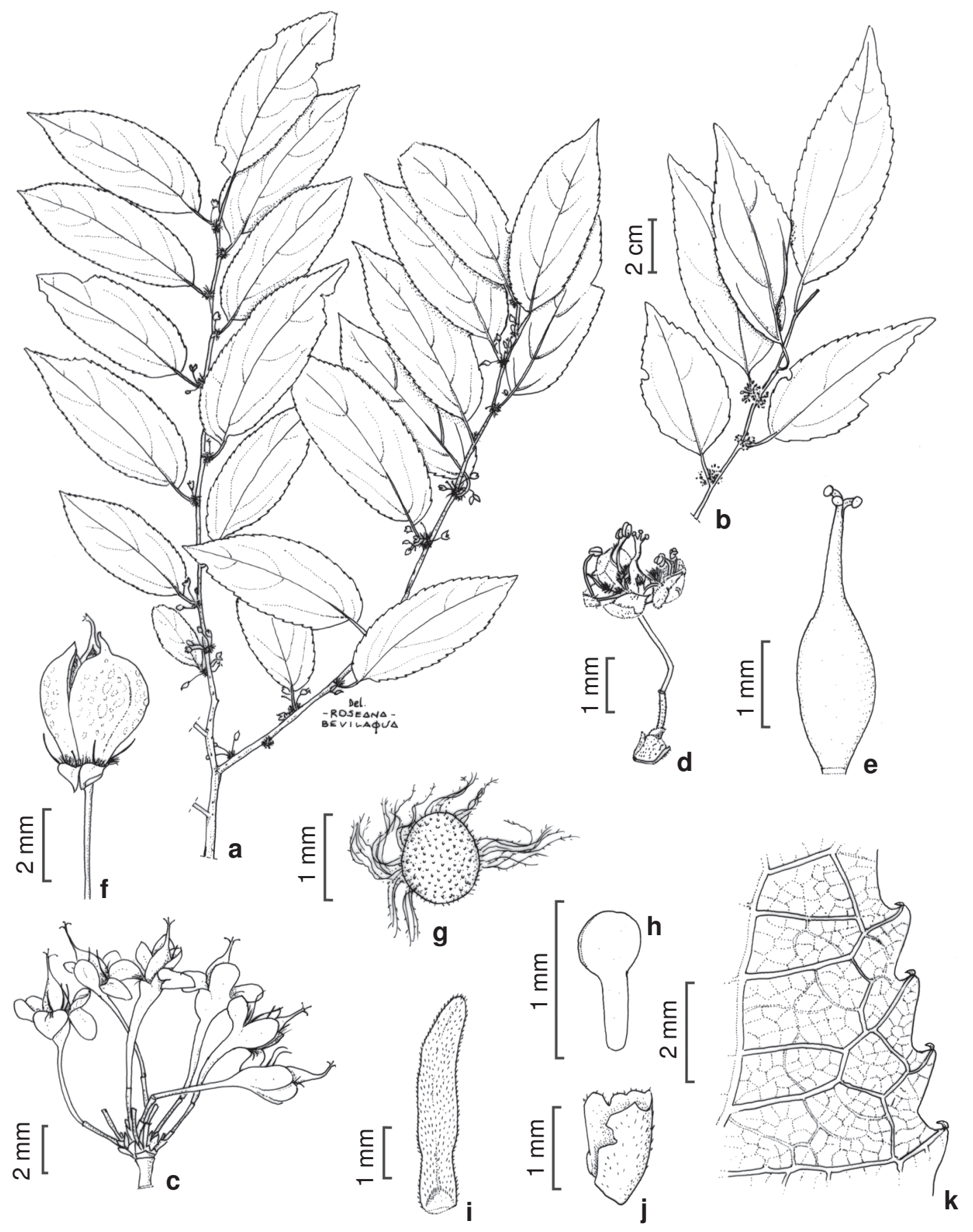

Figura 7 - Casearia obliqua - a. ramo com frutos; b. ramo com flores; c. detalhe da inflorescência; d. flor aberta; e. gineceu com estilete tripartido; f. fruto com glândulas no epicarpo; g. semente com arilo fibroso; h. embrião reto; i. estípula; j. bráctea; k. cerdas acentuadas no bordo da lâmina. (a, f-h, k Carvalho s.n. RB 270318; c-e, i, j Duarte 967; B: Farney 4313) 
Casearia obliqua está bem representada no estado do Rio de Janeiro, ocorrendo deste a vegetação de influência marinha até a floresta estacional semidecídual. Suas flores são perfumadas e sua madeira branca apresenta exsudação de goma segundo etiqueta de herbário (W. Barros 239).

Foi colecionada próximo à lagoa em Maricá, ponta do Fundão (M.C.L. Ramos 910), atingindo também a orla da mata em Petrópolis, Morro do Cuca (G. Martinelli 132), crescendo em escarpa, local ensolarado (J.P.P. Carauta 1693). Esta espécie distinguiu-se das demais por apresentar folhas assimétricas e poucas nervuras secundárias, sempre curvadas ascendentes.

8. Casearia oblongifolia Cambess. in SaintHilaire, Fl. Bras. Merid. 2: 234. 1829.

Figs. 8, 14b

Arbusto a arvoreta $2-8 \mathrm{~m}$ alt.; tronco com casca lisa, com espinhos, verde; ramos com espinhos, tricomas adpressos laxos a glabrescentes, esverdeados; estípulas 3-6×1$1,5 \mathrm{~mm}$, levementes deltóides a subuladas, mais frequentemente encontradas no ápice dos ramos, persistentes em alguns exemplares, esparsamente pubescentes, caducas. Folhas persitentes; pecíolo 5-8 $\mathrm{mm}$ compr., alvo, levemente piloso a glabrescente, subcilíndrico, canaliculado; lâmina (8-) $11,5-15,5 \times 5-6,5 \mathrm{~cm}$, coriácea (quando jovem cartácea), com glândulas na superfície, levemente discolor verde, oblongolanceolada, obovada-lanceolada a lanceolada, adulta glabra a levemente pilosa na nervura primária; ápice largamente acuminado a atenuado; base levemente obtusa, largamente cuneada a curto atenuada; bordos levemente serreados com glândulas nos dentes, folhas jovens com dentes mais visíveis e margens levemente revolutas entre os dentes, traços translúcidos dispersos por toda lâmina e pontos translúcidos distribuídos pelos bordos, 6-10 pares de nervuras secundárias ascendentes, reticulado das veias e vênulas laxos, nervuras são mais proeminentes na face abaxial, nitidas na face adaxial. Inflorescências fasciculadas, (8-)10-17 flores por axila, sésseis, tricomas adpressos, alvos; brácteas ca. $2 \times 1,5 \mathrm{~mm}$, membranáceas, ovadas; bractéolas ca. $1 \times 1,2 \mathrm{~mm}$, ovadas. conchiformes, membranáceas; pedicelos $0,6-1,2 \mathrm{~cm}$ compr., cilíndricos, articulados próximos a base, estrigosos. Botões globosos, ovados a oblongoovados, esparsamente estrigosos; sépalas $5 \times$ $1,5-2,5 \mathrm{~mm}$, soldadas na base, oblongas, com glândulas nos lobos, esverdeadas, tricomas adpressos esparsos, alvos; estames 8, filetes ca. $2 \mathrm{~mm}$ compr., cilíndricos, soldados na base do disco, alvos, glabros com tricomas adpressos e esparsos; anteras amarelas, deltóides, ovadodeltóides, glândula apical diminuta, às vezes difícil de ser visualizada; lobos do disco 1,5-2 mm compr., achatados, vilosos, alvos, intercalados com os filetes; ovário ovado, viloso; estilete inteiro, curto, espesso, alvo; estigma inteiro, arredondado a capitado. Fruto ca. 1,7 × 1,2 cm, globoso a oblongo-globoso, verde, esparsamente piloso, glabrescente; sementes ca. 30, ovado-poliédricas, arilo carnoso, franjado, amarelo-alaranjado, quando removido deixando uma carnosidade na testa, testa foveolada, cor avermelhada a marrom, endosperma carnoso, ovado, com depressão circular no ápice mais largo, avermelhado, embrião reto, foliáceo, alvo.

Nome vulgar: pau-de-laranja.

Material selecionado: BRASIL. RIO DE JANEIRO: Cachoeira de Macacu, fazenda Consorciadas Sertão, 7.X.2000, bt. e fl., F. M. B. Pereira 13/039 (RFA 16863); Macaé, fazenda São Lazaro, 1.XII.1994, bt., D. Araújo 10199 (GUA); Magé, Rio Macacu, 17.VI.1977, fr., D. Araújo 1782 (GUA); Parati, APACAIRUÇU, 9.XII.1993, bt. efl., R. Marquete et al. 1421 (RB); Rio Bonito, Braçanã, 28.X.1972, bt. efl., P. Laclette 219 (R); Rio de Janeiro, ign. s.d., fl, A. St. Hilaire s.n. (holótipo P!, fragmento F!, foto F 34899); Rio das Ostras, REBIO União, estrada para o curral, 16.VIII.2001, fr., J. M. A. Braga 6802 (RB); Saquarema, Reserva Ecológica Estadual de Jacarepiá, 15.I.1991, fr., D. Araújo 9231 (GUA); Silva Jardim, REBIO de Poço das Antas, 29.XI.1992, bt. e fl., H. C. Lima 4568 (RB). Distribuição geográfica e habitat: Brasil: BA, ES e RJ. Vegetação de influência marinha (no cordão arenoso e no interior da mata); floresta ombrófila densa submontana degradada; vegetação secundária. No estado do Rio de Janeiro, Casearia oblongifolia 


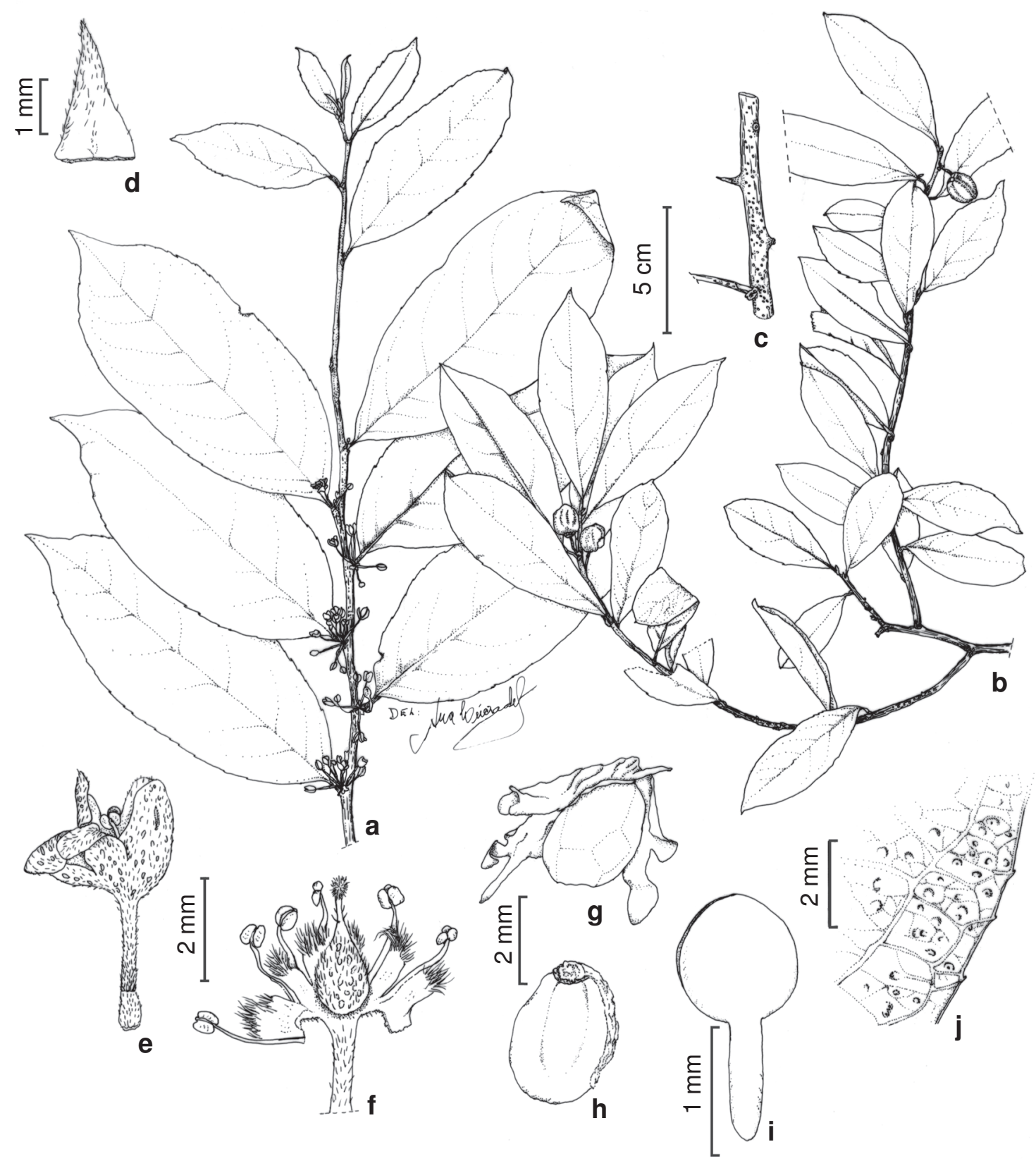

Figura 8 - Casearia oblongifolia - a. ramo com flores e botões; b. ramo com frutos; c. detalhe do ramo com espinhos; d. estípula; e. flor; f. flor aberta, mostrando gineceu e androceu intercalados com os lobos do disco; g. semente poliédrica com arilo franjado; h. semente com resto do arilo removido; i. Embrião reto; j. Cerdas diminutas no bordo da lâmina. (b, c, g-i Braga 6802; a, j Bovini 2244; e, f Pessoal do Horto RB129456; d Marquete 1268) 
ocorre desde as partes mais baixas com solos arenosos até a Serra do Mar. Até o momento não temos relatos de sua ocorrência para áreas de floresta estacional semidecídual. Espécie heliófita ou de luz difusa no interior da floresta. Dados fenológicos: é encontrada em botões e flores nos meses de março e maio e de outubro a dezembro. Frutos em dezembro a fevereiro, junho e agosto.

Os materiais citados por Guimarães et al. (1971), colecionados por Duarte 4795 e Ducke \& Kuhlmann s.n. (RB 3293), como Casearia aculeata foram tratados evisados aqui como $C$. oblongifolia. O erro deu-se provavelmente devido a estas espécies serem muito semelhantes.

9. Casearia pauciflora Cambess. in SaintHilaire, Fl. Bras. Mer. 2:235. 1829.

Figs. 9, 14c

Árvore, arvoreta ou arbusto 1,5-12 (-16) m alt.; tronco com casca estriada, acinzentada; ramos inermes, flexuosos, base glabrescente e ápice pubescentes, marrons, esparsamente lenticelados; estípulas ca. 2,5 mm compr., subuladas, puberulentas, caducas. Folhas persistentes; pecíolo 3-14 mm compr., esparsamente puberulento, subcilíndrico, levemente canaliculado; lâmina 6,3-13 ×3,0$5,3 \mathrm{~cm}$, cartácea, discolor verde, elíptica, elíptico-ovada, indumento hirsuto-velutino sobre as nervuras primária e secundária; ápice acuminado; base atenuada; bordos serreados com glândulas no ápice das cerdas; pontos translúcidas mais visíveis nas folhas jovens, nos bordos, traços espalhados na parte central da lâmina, 5 pares de nervuras secundárias ascendentes (as da base da lâmina quase opostas e longamente ascendentes), reticulado das veias e vênulas laxo, em ambas as faces, mais proeminente abaxialmente. Inflorescências fasciculadas, paucifloras, sésseis, tomentosas; brácteas 1,5 mm compr., reunidas na base dos pedicelos, ovadas, conchiformes, pilosas; pedicelos $4 \mathrm{~mm}$ compr.; cilíndricos, articulados próximos à base, tomentosos; botões obovadooblongos, tomentosos; sépalas $4 \times 1,5 \mathrm{~mm}$, livres, ovado-oblongas, pilosas em ambas as faces; estames 10, filetes $2 \mathrm{~mm}$ compr., livres, glabros; anteras oblongas, sem glândula apical; lobos do disco 1 mm compr., oblongo-clavados, tomentosos, intercalados com os filetes; ovário oblongo-ovado a subgloboso, híspido-viloso; estilete inteiro, curto, glabro; estigma inteiro, capitado, hirsuto. Fruto 2,7-3×2,6-3 cm, globoso, amarelo, com máculas alvas, esparsamente piloso, tardiamente deiscente; sementes $8 \times 7 \mathrm{~mm}$, subglobosas a ovóides, testa lisa, arilo carnoso, franjado, amarelado, endosperma carnoso, cor amarela, embrião ca. $8 \mathrm{~mm}$ compr., reto, cotilédone foliáceo, cordado próximo ao eixo hipocótilo-radicula.

Nome vulgar: bacupari

Material selecionado: BRASIL. RIO DE JANEIRO: Angra dos Reis, Ilha Grande, REBIO Estadual da Praia do Sul, 4.VII.1991, est., R. Ribeiro et al. 1990 (GUA); Cachoeira de Macacu, Estação Ecológica do Paraíso, 8.VI.1992, est., B. C. Kurtz et al. s.n. (RB 328338); Campos dos Goytacazes, Dist. Morro do Côco, 9.XI.2004, fr., J. M. A. Braga 7609 (RB); Guapimirim, Granja Monte Olivete, 27.V.1994, fr., $M$. G. Bovini et al. 412 (RUSU); Itatiaia, 1918, bt. e fl., C. Porto s.n. (RB 21432); Magé, Paraíso, 25.X.1984, est., H. C. Lima et al. 2344 (RB,GUA); Magé/ Cachoeira de Macacu, Paraíso, 29.VIII.1991, fr., $R$. Guedes et al. 2231 (RB); Mendes, fazenda São José das Palmeiras, 5.XII.1992, fl., T. Konno 96 (RUSU); Nova Friburgo, Reserva Ecológica Municipal de Macaé de Cima, 7.XI.1988, est., R. Guedes et al. s.n.. (RB 291904, RUSU); Paraíba do Sul, fazenda do Sobral (antigo governo) do Dr. Viriato de Medeiros, 15.X.1881, bt. e fl., J. Saldanha \& A. C. W. Schwancke s.n. (R 51755); Parati, fazenda do Gibrail, subindo a trilha da Bica d'água, 12.V.1994, fl. e fr., R. Marquete 1817 (RB); Petrópolis, Araras, base da Pedra Maria Comprida, 23.III.1968, bt. e fl., D. Sucre et al. 2546 (RB); Rio de Janeiro, Corcovado, 28.II.1868, bt. e fl., A.F.M. Glaziou 2564 (R); D.F. Dois Irmãos, 22.XI.1888, fl., A. C. W. Schwacke s.n. (R 51697); Santa Maria Madalena, Parque Estadual do Desengano, caminho para Ribeirão Vermelho, 25.VII.1984, fr., M. B. Casari et al. 1170 (GUA); Teresópolis, fazenda Boa Fé, 10.I.1943, fl., H. P. Velloso s.n., (R 38400).

Material adicional: MINAS GERAIS: s.d., fl., A. StHilaire s.n., (holotipo: P!, fragmento F!, foto:34900). Distribuição geográfica e habitat: Brasil: MG, ES e RJ. 


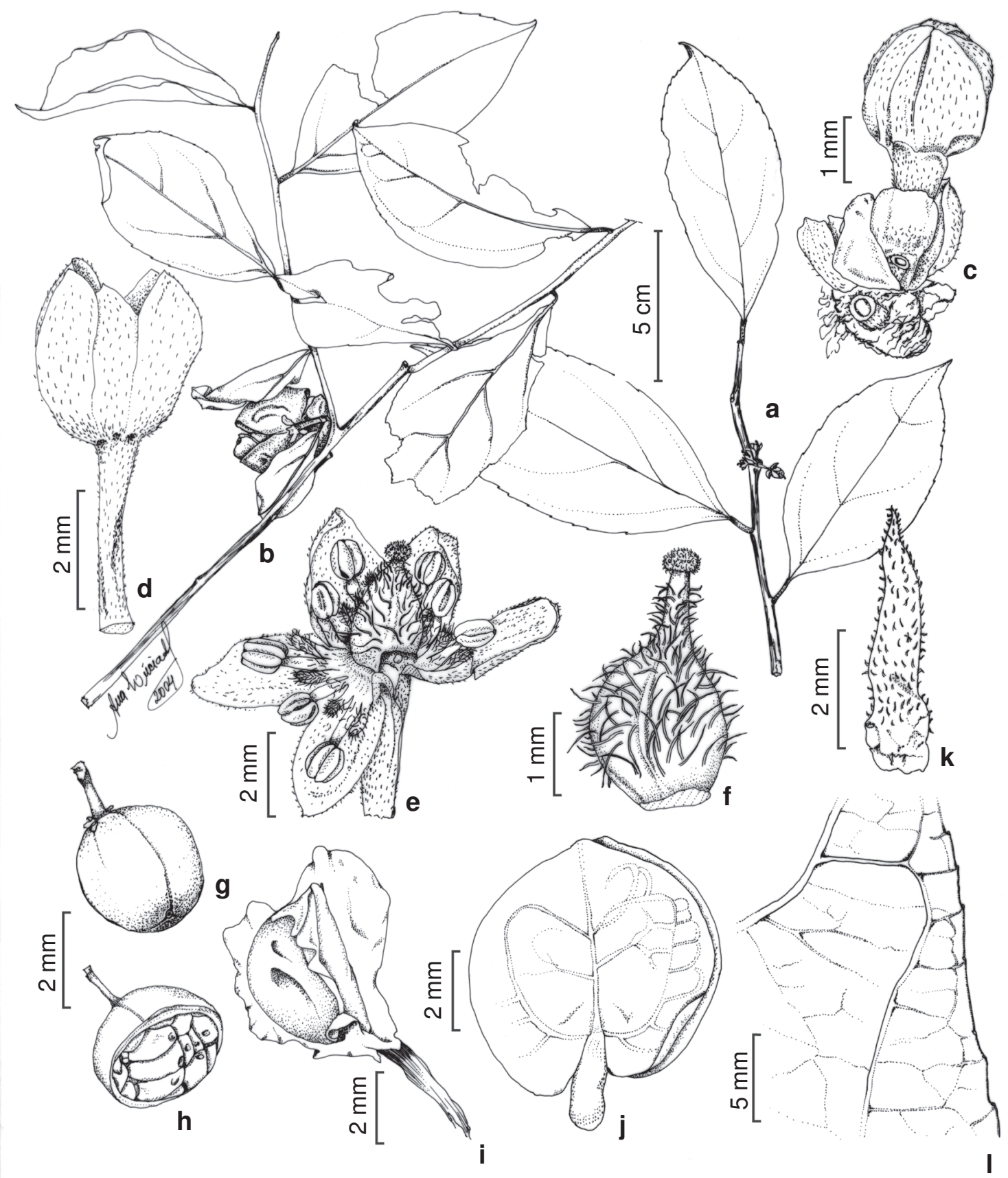

Figura 9 - Casearia pauciflora - a. ramo com flores; b. ramo com fruto; c. botão floral e brácteas; d. flor em antese; e. flor aberta com lobos do disco intercalados aos filetes e ovário; f. ovário com tricomas; g. fruto; h. fruto em corte transversal com sementes; i. semente com arilo carnoso, franjado; j. embrião reto; k. estípula; 1. cerdas diminutas no bordo da lâmina (c-f, k Carauta 2454; b Cardoso 218; g-j Cardoso 227; a, 1 Marquete 1817). 
Floresta ombrófila densa (perto do riacho, dossel com ca. $25 \mathrm{~m}$ altura); vegetação secundária de encosta. Segundo H.C. Lima 3444 (RB), ocorre ocasionalmente na submata da floresta de encosta, na margem do rio Macaé em Nova Friburgo. No estado do Rio de Janeiro, Casearia pauciflora ocorre em vegetação de floresta ombrófila densa e muito raramente pode ser encontrada em floresta estacional semidecídual. Espécie pode ser encontrada tanto em luz difusa, quanto em luz contínua (heliófila).

Dados fenológicos: é encontrada em botões e flores de outubro a maio. Os frutos imaturos e maduros foram colecionados fevereiro a maio e de julho a novembro.

10. Casearia selloana Eichler in Mart. \& Eichler, Fl. bras. 13(1): 483. 1871.

Figs. 10, 14d

Arbusto, árvore 3-6 m alt.; ramos inermes, levemente em ziguezague no ápice, glabros, amarronzados, densamente lenticelados; estípulas 1-2×1 mm, subdeltóides, cerdas nos bordos, esparsas do meio para o ápice, caducas. Folhas persistentes; pecíolo 5-7 cm compr., semicilíndrico, levemente canaliculado, glabros; lâmina (5,5-)6,5-7,5(-15)×3,5-5,4 cm, coriácea, discolor verde, glabra, oblongo-ovada a oblongo-lanceolada; ápice curto-cuspidado, obtuso a levemente cuspidado; base curtoatenuada a levemene assimétrica; bordos inteiros a obscuramente denticulados na face abaxial, levemente revoluto entre as cerdas, com glândulas arredondadas pouco proeminentes; pontos e traços translúcidos dispersos na lâmina, 4-6 nervuras ascendentes, reticulado das veias e vênulas denso, mais proeminente na face abaxial. Inflorescências glomérulos, multifloras, sesséis, pilosas; brácteas ovadas, transparentes, pilosas; flores com pedicelos cilíndricos, articulados próximos à base, pilosos para o ápice, esparsamente pilosos a glabrescentes para base, botões oblongos, esparsamente tomentosos; sépalas 2-2,5×1 mm, soldadas próximo à base, formando um tubo curto, ovadas, esverdeadas, pilosas com bordos barbados; estames 10, filetes 1 mm compr., cilíndricos, esparsamente vilosos; anteras globosas a oblongas, glândula apical arredondada, glabra; lobos do disco 0,5 mm compr., clavados, alvo-esverdeados, vilosos, intercalados com os filetes e soldados a base das sépalas; ovário ovado, glabro; óvulos ca. 10; estilete tripartido, espesso, esparso viloso; estigmas capitados, glabros. Fruto $6 \times 3,5 \mathrm{~mm}$, levemente obovado a obovadooblongo, imaturo verde, glabro, glândulas arredondadas na superfície externa; sementes 10, ca. $0,5 \mathrm{~mm}$ compr., levemente arredondadas a angulosas, escuras; arilo franjado, amarelado a transparente, envolvendo quase toda semente. Nome vulgar: pau-preto.

Material selecionado: BRASIL. RIO DE JANEIRO: Nova Friburgo, Lumiar, 18.V.2001, est., A. Quinet 18/94 (RB 397531, RFA); Petrópolis, Vale Bonsucesso, 1.X.1968, fl., D. Sucre 3984 (RB); São José do Vale do Rio Preto, 6.XI.2000, fr., F. M. B. Pereira $49 / 49$ (RB 397530, RFA).

Material adicional: BAHIA, entre Bahia e Vitória, s.d., fl., F. Sello s.n. (isolectotipos: P!).

Distribuição geográfica e habitat: Brasil: PB, AL, ES e RJ. Floresta ciliar, vegetação secundária, savana arborizada e savana estépica. No estado do Rio de Janeiro, Casearia selloana ocorre em vegetação de floresta ombrófila densa, na Serra do Mar e, na floresta estacional semidecídual. Espécie de luz difusa no interior da floresta, em áreas antropizadas recebe luz direta; não atinge o dossel da floresta.

Dados fenológicos: é mais encontrada em botões eflores nos meses de julho, agosto e outubro. Frutos imaturos em novembro e maduros em dezembro.

Casearia selloana é muito pouco representada nos herbários. O baixo número de exemplares nas coleções de herbário pode ser devido à grande ação antrópica nos locais de sua ocorrência.

11. Casearia sessiliflora Cambess. in SaintHilaire, Fl. bras. Mer. 2: 231. 1829; Eichler in Mart., \& Eichler, Fl. bras. 13(1): 473. 1871.

Figs. 11, 14e

Arbusto 0,5 m alt.; ramos inermes, glabros a esparsamente pubescentes no ápice dos ramos, acinzentados, lenticelas esparsas, arredondadas; estípulas $2 \times 0,5 \mathrm{~mm}$, subuladas a levemente conchiformes, esparsamente pubescentes no dorso, caducas, raramente persistem na base da inflorescência. Folhas 


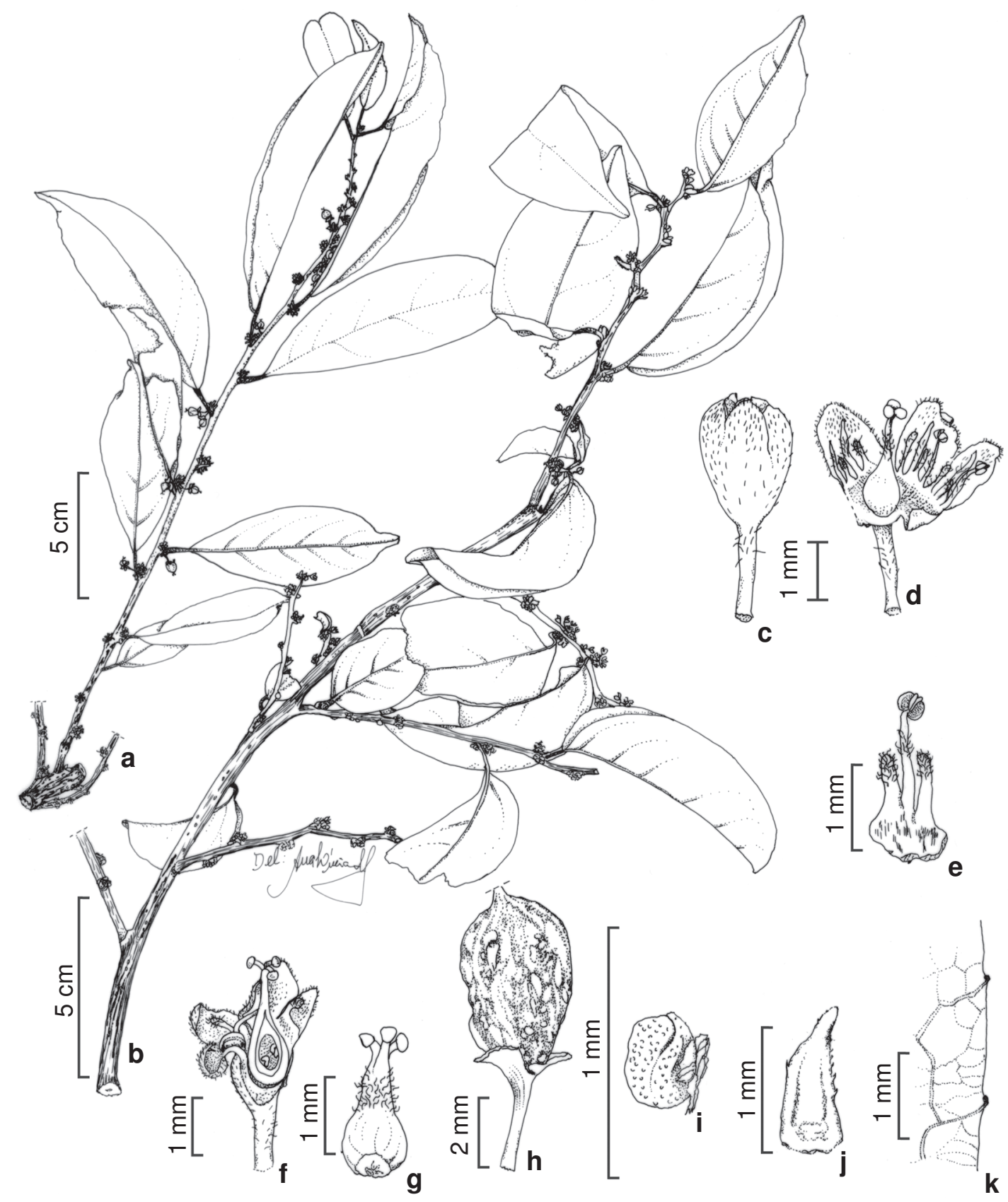

Figura 10 - Casearia selloana - a. ramo com frutos jovens; b. ramo com flores; c. flor; d. flor aberta; e. detalhe dos lobos do disco intercalados com o filete; f. flor mostrando ovário em corte longitudinal; g. ovário; h. fruto; i. semente com arilo; j. estípula; k. cerdas diminutas no bordo da lâmina foliar. (a, h-k Sucre 4203, b-g Sello s.n. P!) 


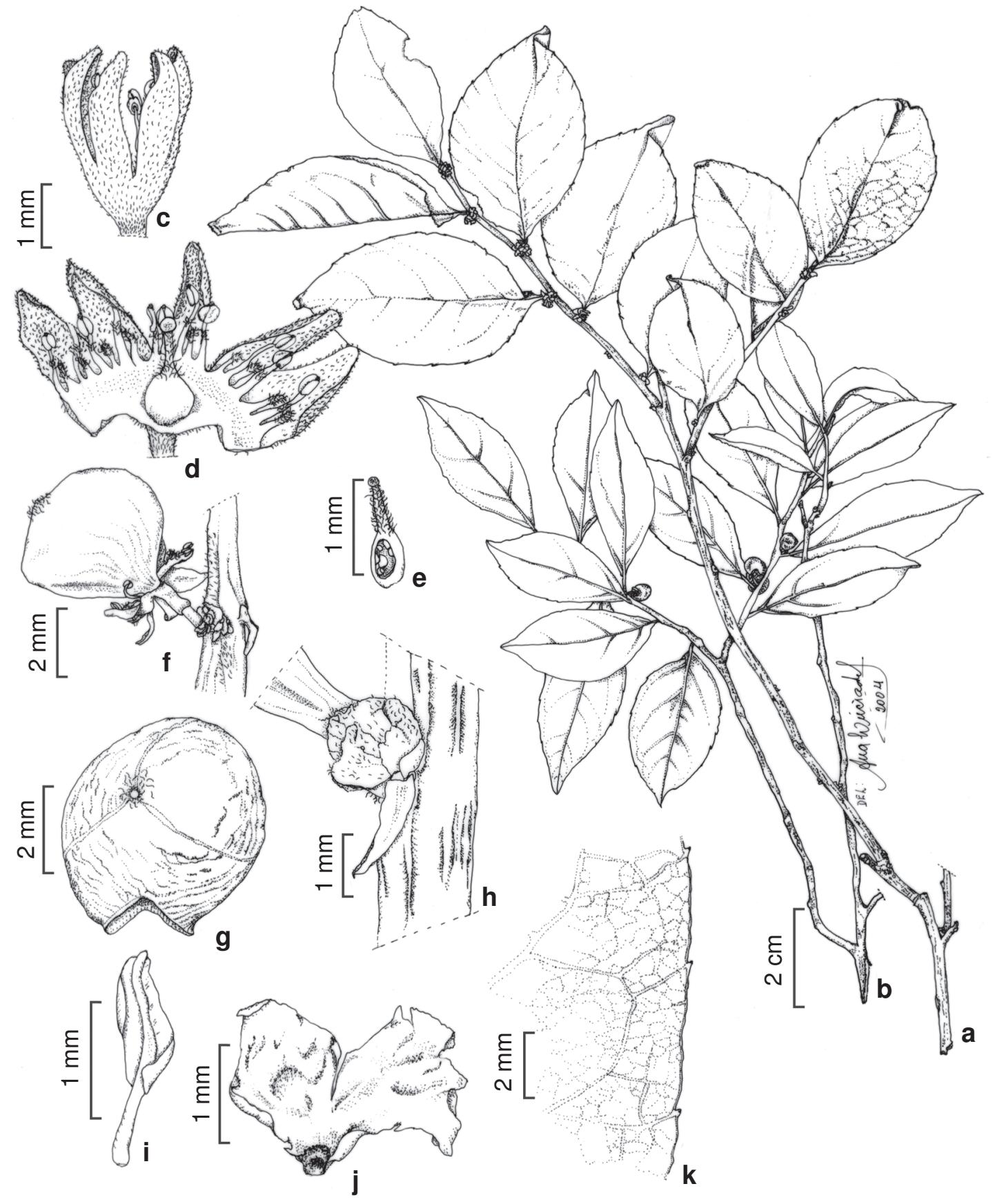

Figura 11 - Casearia sessilifolia - a. ramo com flor; b. ramo com fruto; c. flor com sépalas eretas; d. flor aberta; e. ovário em corte longitudinal mostrando óvulo fixos a parede; f. fruto com sépalas, androceu e lobos do disco persistentes; g. fruto com marcas da abertura da cápsula; h. detalhe da estípula e das brácteas; i. bráctea; j. embrião reto; k. cerdas diminutas no bordo da lâmina. (b, f-h, j Hemmendorff 465; a, c-f, i St. Hilaire cat. B.2, $n^{\circ} 218 s$ ) 
persistentes, pecíolo 2-4 mm compr., espesso, semi-cilídrico a levemente canaliculado, pubescente quando jovem a glabrescente na maturidade, lâmina 5,5-7,5 × 2-4,2 cm, membranácea, discolor, verde, glabra, lanceolada a larga oblongo-lanceolada, ápice acuminado a raramente curto-acuminado, base largoatenuada, bordos serreados com cerdas curtas; pontos e traços translúcidos densamante dispersos na lâmina, nervuras secundárias (4-) $6(-7)$ pares ascendentes, reticulado das veias e vênulas denso, mais proeminente na face abaxial, pouco visível a olho nu. Inflorescências glomérulos, paucifloras, sésseis, pubescentes, flores subsésseis; brácteas ovado-lanceoladas, conchiformes, membranáceas, transparentes, escariosas, amarelo-alvacentas, flores subsésseis a sésseis, cilíndricos, articulados na base, tomentosos. Botões oblongos, tomentosos, sépalas 2,5-3×1 mm, soldadas próximo à base, formando um tubo curto, oblongo-ovadas, esverdeadas, tomentosas; estames 10 , desiguais, filetes $0,5-1 \mathrm{~mm}$ compr., subulados, esparsamente vilosos na parte mediana; anteras subglobosas a oblongas, diminutas (ca. 0,2 mm), glândula apical arredondada, glabra; lobos do disco 0,5-1 mm compr., clavados, alvoesverdeados, vilosos, intercalados com os filetes; ovário subgloboso a levemente ovado, viloso acima do meio, óvulos poucos; estilete inteiro, delgado, viloso; estigma inteiro, capitado, glabro. Fruto $7 \times 7 \mathrm{~mm}$, globoso, negro, viloso somente na inserção com o estilete, sementes 6 , ca. $4 \times 2 \mathrm{~mm}$, levemente ovadas a poliédricas, alaranjadas, arilo franjado amarelo, embrião 3 mm compr., reto, cotilédones membranáceos, levemente oblongos.

Nome vulgar: noz-de-bugre.

Material selecionado: BRASIL. RIO DE JANEIRO: Rio de Janeiro, Sítio do Pires, 1816 a 1821, fl., A. St. Hilaire cat. B2 n. 218 (Holótipo P!, frag. F!- 935715, foto F! 34903); Restinga de Mauá, 24.VI.1901, fr., $E$. Hemmendorff 424 (S); ibidem, 26.VI.1901, fr., E. Hemmendorff 465 (S); Campos dos Goytacazes, IV.1918, fl., A. J. Sampaio 2992 (R); São João da Barra, Atafona, III.1939, fl., A.J. Sampaio s.n. (R).

Distribuição geográfica e habitat: Brasil: Rio de Janeiro, em vegetação secundária e vegetação com influência marinha (em solo arenoso).
Dados fenológicos: encontrada em flor em março e abril, fruto imaturo no mês de junho.

Casearia sessiliflora não é encontrada na natureza há mais de 60 anos, sendo conhecida apenas através dos materiais supra citados. Esta espécie, endêmica do estado do Rio de Janeiro, provavelmente está extinta.

12. Casearia sylvestris Sw., FI. Ind. Occid. 2: 752. 1798; Willdenow, Sp. PI. 2: 628. 1799.

Figs. 12, 14f

Casearia sylvestris Sw. var. lingua (Cambss.) Eichler in Mart.\& Eichler, Flora bras. 13(1): 482. 1871. Syn. nov.

Árvore ou arvoreta 3-9(-18) m alt.; tronco com casca lisa a levemente fissurada a fissurada, acinzentada a marrom, camada corticosa fina a grossa; ramos inermes, delgados e patentes, puberulentos a glabrescentes, acinzentados, mais ou menos lenticelados; estípulas $1 \mathrm{~mm}$ compr., subovadas, puberulentas, caducas. Folhas persistentes; pecíolo 3-5 mm compr., subcilíndrico, levemente puberulento, delgado; lâmina 6-11 × 2-3,5 cm, cartáceas, concolor a levemente discolor, verde, lanceoladoovada, oblongo-lanceolada a lanceolada, glabra, ocasionalmente curto pubescente na face abaxial, principalmente sobre as nervuras primária e secundárias; ápice acuminado a falcado; base freqüentemente assimétrica, cuneada; bordos mucronado-serreados a serreados; pontos e traços translúcidos densos por toda lâmina, 5-6 pares de nervuras secundárias ascendentes, reticulado das veias e vênulas denso, mais proeminentes abaxialmente. Inflorescências fasciculadas, multifloras, sésseis, variáveis no indumento; brácteas 0,5 mm compr., diminutas, ovadas, pubescentes, pedicelos 2-4 mm compr., cilíndricos, delgados, articulados próximo ao meio ou abaixo, pubescentes a glabrescentes. Botões obovados a globosos, esparsamente tomentosos, sépalas 1,5 × 1-1,5 mm, unidas na base, largamente ovadas, esverdeadas a alvacentas, glabras a tomentosas ou ciliadas na margem; estames 10 , filetes $1-1,5 \mathrm{~mm}$ compr., livres, pilosos na base e subglabro no ápice, anteras globosas, glândula apical crassa, glabra; lobos do disco 
$1 \mathrm{~mm}$ compr., clavados, alvacentos, densamente pilosos, unidos na base e intercalados com os filetes; ovário ovóide, glabro; estilete inteiro, delgado, subglabro; estigma trilobado, globoso. Fruto $4 \times 4 \mathrm{~mm}$, globoso, anguloso, negro, glabro, sementes 5, 2,5 × 1,5 mm, oblongas, testa escrobiculada, alaranjada, arilo franjado, carnoso, envolvendo parcialmente a semente, alaranjada a vermelha, endosperma crasso; embrião ca. $1,5 \mathrm{~mm}$ compr., reto, alvo; cotilédones crassos, alvos, arredondados.

Nome vulgar: erva-de-lagarto; café-do-mato; canela-de-veado, teu, tiú, canela, teyú, guaçatonga, erva-de-lagarto, cafezinho-do-mato, pão-de-lagarto, guaçatunga, pau-de-lagarto, cafezeiro-do-mato, café-bravo (SP), fruta-desaíra (SP), pau ou herva-de-lagarto (SP).

Material selecionado: BRASIL. RIO DE JANEIRO: Angra dos Reis, Ilha Grande, Reserva Biológica Estadual da Praia do Sul, 4.VII.1991 est., R. Ribeiro et al. 2004 (GUA); Araruama, Rio Bacaxá, 16.VI.1976, bt. e fl., J. P. P. Carauta 2078 (GUA); Búzios, 11.VII.1996, bt., D. Araújo 10439 (GUA); Cachoeira de Macacu, 30.V.1978, bt., M. C. Vianna et al. 1322 (GUA); Campos dos Goitacazes, 5.VII.2004, bt., R. Marquete et al. 3477 (RB); Cantagalo, 26.IX.2001, est., S. M. Souto \& J. A. C. Paula 324 (RBR); Carapebus, 29.V.2002, est., $R$. Marquete et al. 3285 (RB); Cordeiro, 29.VII.1973, fl., D. Araújo 382 (RB); Duque de Caxias, Reserva da Petrobrás, 6.V.1997, bt. e fl., J. M. A. Braga et al. 4024 (RB); Itaocara, fazenda da passagem, 18.VIII.1980, bt. e fl., M. B. Casari 323 (GUA); Itatiaia, PARNA do Itatiaia, 30.V.2002, fl., $R$. Marquete et al. 3297 (RB); Magé, 5.XII.1984, est., G. Martinelli \& S. Pessoa 10542 (GUA, RB); Magé/ Cachoeira de Macacu, Estação Ecológica Estadual de Paraíso 1.XI.1991, est., R. Guedes et al. s.n. (RB 314242); Mangaratiba, 26.V.1998, bt. e fl., $R$. Marquete et al. 2927 (RB); Maricá, 19.II.1997, M. C. Lemos Ramos 1856 (RB); Mendes, 32, 11.VI.1992, bt. e fl., T. Konno 56 (RUSU); Miguel Pereira, 25.VI.1978, bt. efl., L. F. Aguiar 23 (GUA); Miracema, 26.VII.2001, est., S. M. Souto \& J. M. Lima 181 (RBR); Natividade, 7.VII.2004, bt., R. Marquete et al. 3486 (RB); Niterói, Parque Estadual da Serra da Tiririca, 18.VI.2002, bt. e fr., A. A. M. Barros 1602 (RFFP); Nova Friburgo, 16.V.1990, est., R. Guedes et al. s.n. (RB 291909); Nova Iguaçu, REBIO Tinguá, 13.VI.1996, bt. e fl., M. V. L. P. Moura et al. 629 (RBR); Paraíba do Sul, 26.VII.2004, fl., R. Marquete et al. 3511 (RB); Parati, 27.VI.1995, bt.,fl. e fr., $R$. Marquete et al. 2179 (RB); Petrópolis, s.l., 29.X.1875, bt. e fl., A. F. M. Glaziou 8267 (R); Piraí, fazenda Três Saltos, 2.VIII.1990, bt. e fl., C. F. C. Canella s.n. (RB 288225); Resende, Horto Florestal, 21.VI.1927, bt. e fl., J. G. Kuhlmann s.n. (RB 129459); Rio Claro, Distr. Lidice, 13.X.2004, est., R. Marquete et al. 3567 (RB); Rio das Flores, 29.VII.2004, bt. e fl., R. Marquete et al. 3546 (RB); Rio de Janeiro, s.1., 1844, bt. e fl., Widgren s.n. (R 51709); Santa Maria Madalena, 18.X.1995, est., R. Marquete et al. 2390. (RB); São Francisco de Itabapoana, Tabapuã, 11.XI.2004, fr., J. M. A. Braga 7669 (RB); São João da Barra, Boa Sorte, 12.I.1982, bt. e fl., $H$. Q. Boudet Fernandes et al. 355 (GUA); São José do Vale do Rio Preto, fazenda Belém, 30.VII.2000, bt. e fl., F. M. B. Pereira 14/24 (RFA 24847); São Pedro da Aldeia, Serra de Sapiatiba, 11.IX.2000, bt. e fl., C. Farney \& J. C. Gomes 4158 (RB); Sapucaia, $1^{0}$ distrito, sítio Santa Bárbara, 17.XI.2000, bt., $P$. Schuback 03/52 (RFA 25446); Saquarema, Reserva Ecológica de Jacarepiá, 20.VIII.1990, fl., C. Farney et al. 3205 (RB,GUA); Seropédica, Itaguaí, VII.1952, bt. e fl., H. Monteiro-Filho 3628(RBR); Silva Jardim, REBIO Poço das Antas, 25.V.1994, fl., S. V.A. Pessoa et al. 701 (RB); Teresópolis, Bairro da Posse, 12.VI.1997, fl. e fr., R. Marquete et al. 2804 (RB); Três Rios, 28.VII.2004, fl., R. Marquete et al. 3536 (RB); Valença, distrito de Barão de Juparanã, 30.V.2000, bt., M. L. C. V. Spolidoro et al. 161 (RB); Vassouras, fazenda Cananéia, 11.IX.2002, fl. e fr., $S$. M. Souto \& C. F. Cunha 593 (RBR); Volta Redonda, Santa Rita, 20.V.1989, bt. e fl., J. P. P. Carauta et al. 5862 (GUA, RB).

Material adicional: JAMAICA: ign. 1835, bt, Wright s.n. (provável sintipo: NY!).

Distribuição geográfica e habitat: México, América Central e na maioria dos países da América do Sul. No Brasil ocorre em todos os estados. Floresta ombrófila densa - aluvial, terras baixas, submontana e montana, vegetação de influência marinha, formação barreiras (mata baixa em topo de morro), vegetação secundária, mata higrófila secundária, floresta estacional semidecidual de terras baixas, submontana e montana (mata de tabuleiro ondulado), savanas; floresta ombrófila mista. No estado do Rio de Janeiro, Casearia sylvestris ocorre em todos os tipos de vegetação. Esta espécie é encontrada tanto 


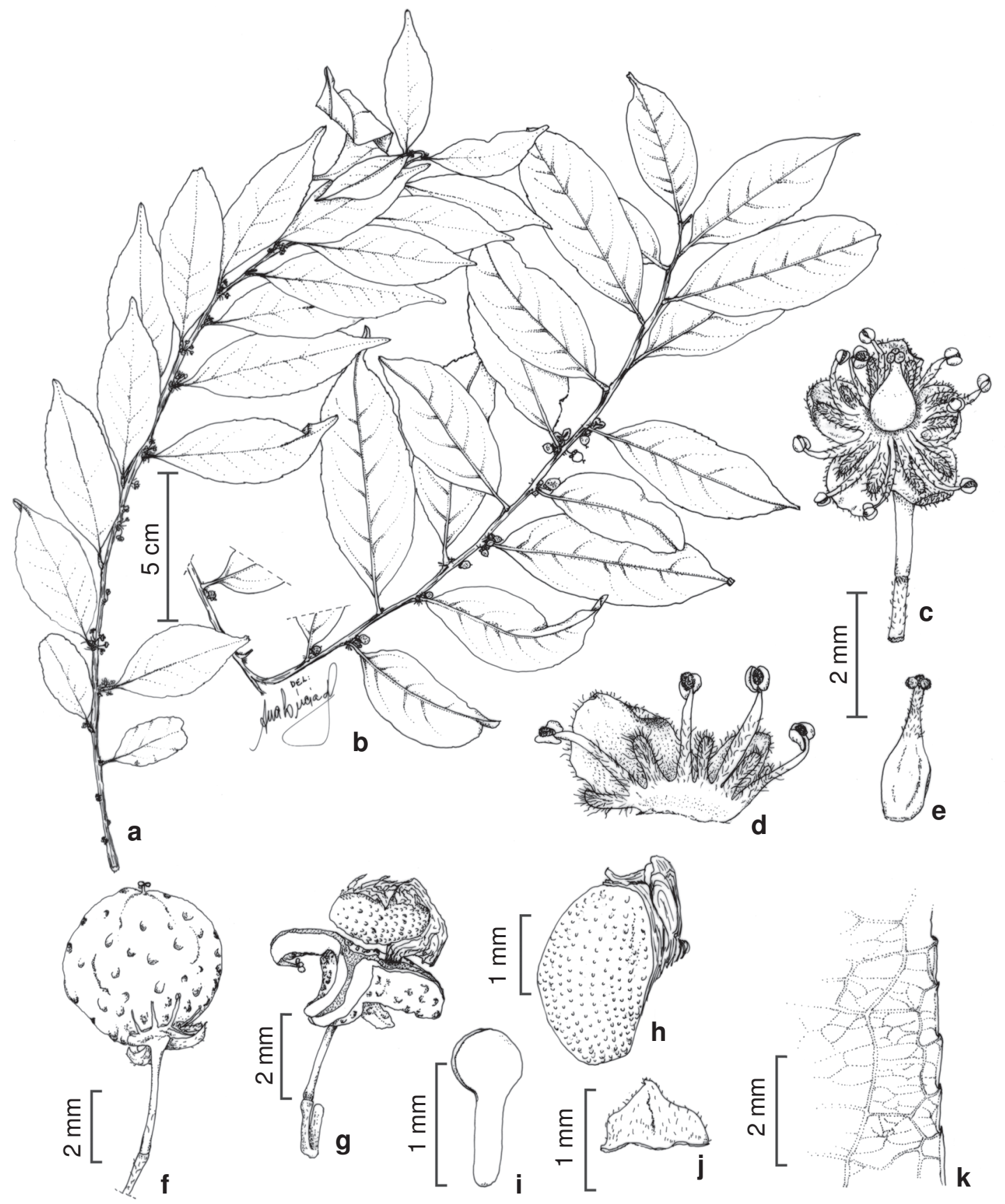

Figura 12 - Casearia sylvestris - a. ramo com flores e botões; b. ramo com frutos; c. flor aberta, mostrando gineceu, androceu e lobos do disco; d. flor aberta, mostrando os estames intercalados com os lobos do disco; e. ovário; f. fruto com glândulas no epicarpo; g. cápsula aberta mostrando semente fixa pelo arilo; h. semente com arilo; i. embrião reto; j. forma da estípula; k. cerdas diminutas no bordo da lâmina. (b, f-j Marquete 3547; a,c-e Marquete 3451; k Marquete 3297) 

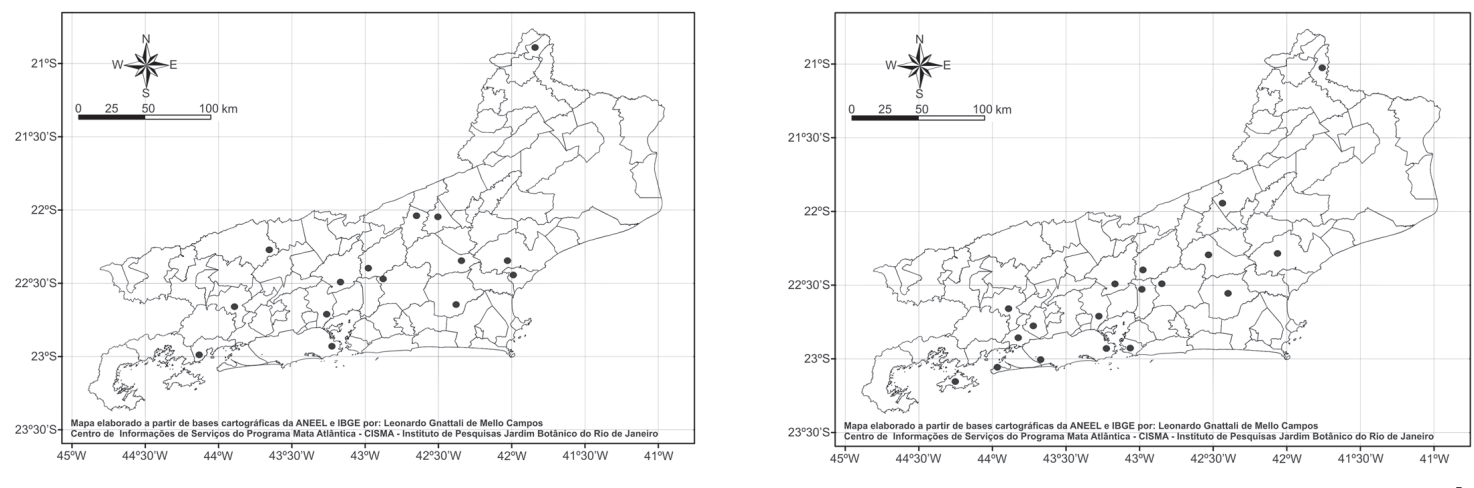

a

b
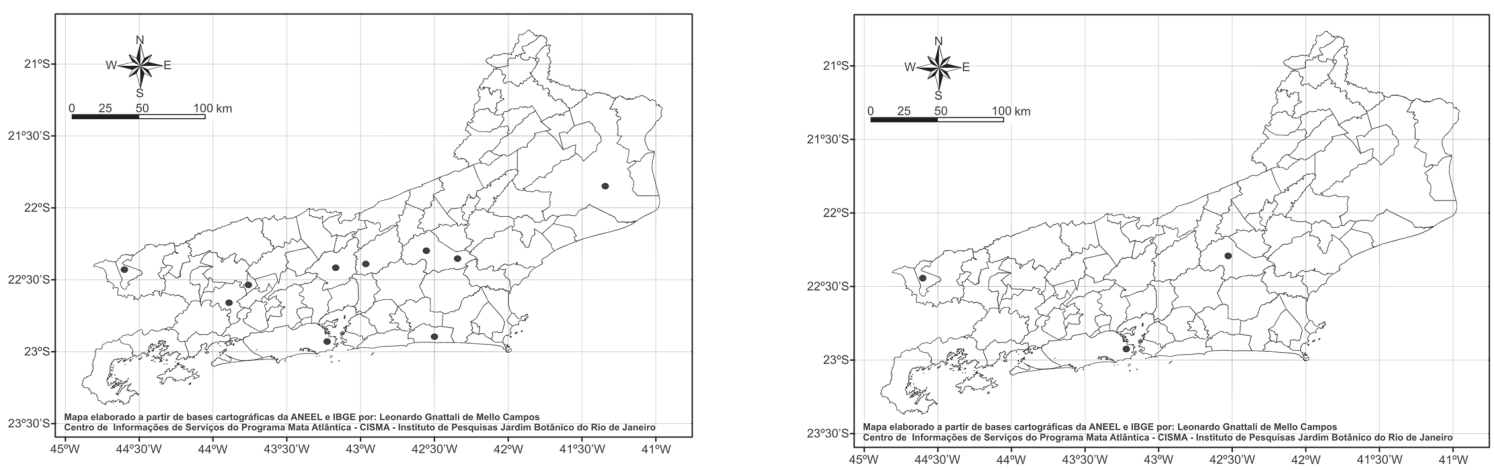

c
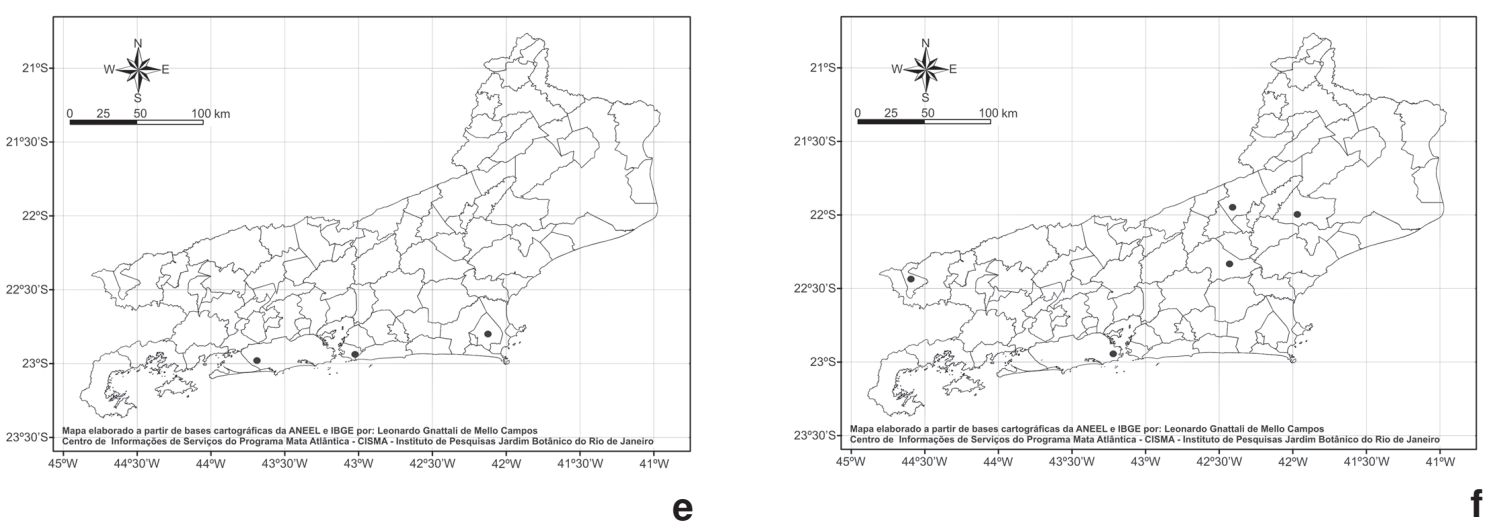

Figura 13 - Distribuição geográfica: a) Casearia arborea, b) C. commersoniana, c) C. decandra, d) C. lasyophylla, e) C. luetzelburgii, f) C. melliodora.

no interior da mata como em áreas antropizadas, sendo uma espécie com grande capacidade de adaptação ao meio. Recebe luz difusa no interior da floresta ou luz direta ao atingir o dossel, ou em áreas degradadas, onde ocorre com menor porte. É uma espécie de ampla distribuição no estado.

Dados fenológicos: botões e flores em janeiro e de março a novembro. É mais colecionada com frutos imaturos e maduros de maio a novembro.

Casearia sylvestris possui ampla distribuição no neotrópico ocorrendo em diferentes formações vegetacionais, sofrendo variações morfológicas principalmente na forma da lamina foliar. Apresenta flores muito aromáticas na antese. $\mathrm{O}$ arilo das sementes, de colorido forte, é atrativo para a avifauna que, segundo D.S. 

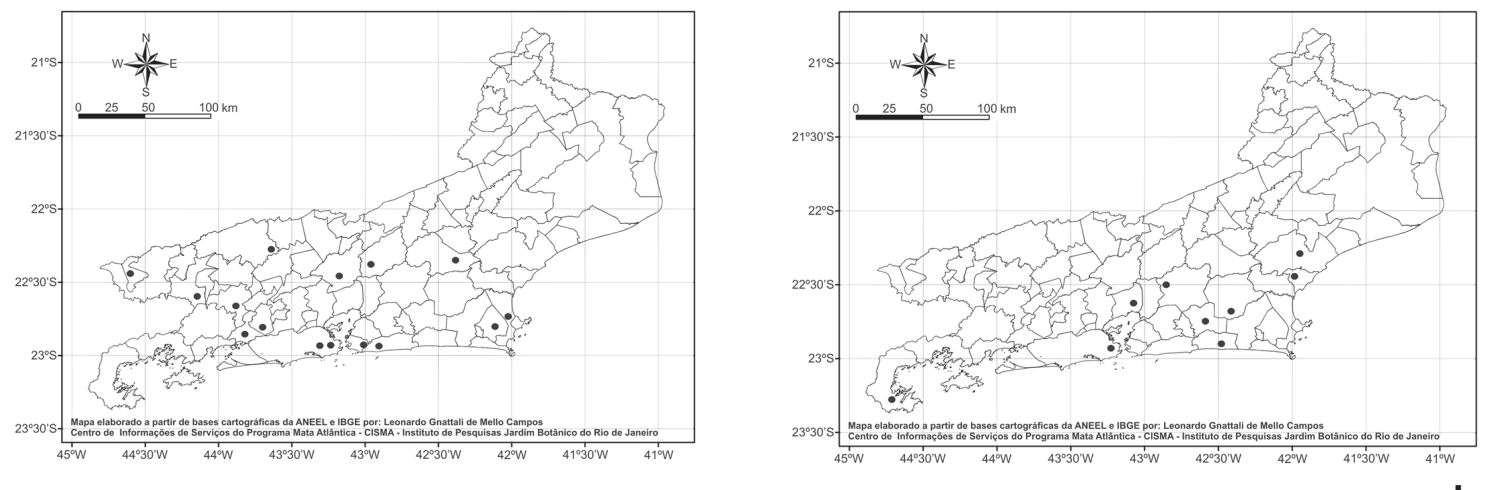

a
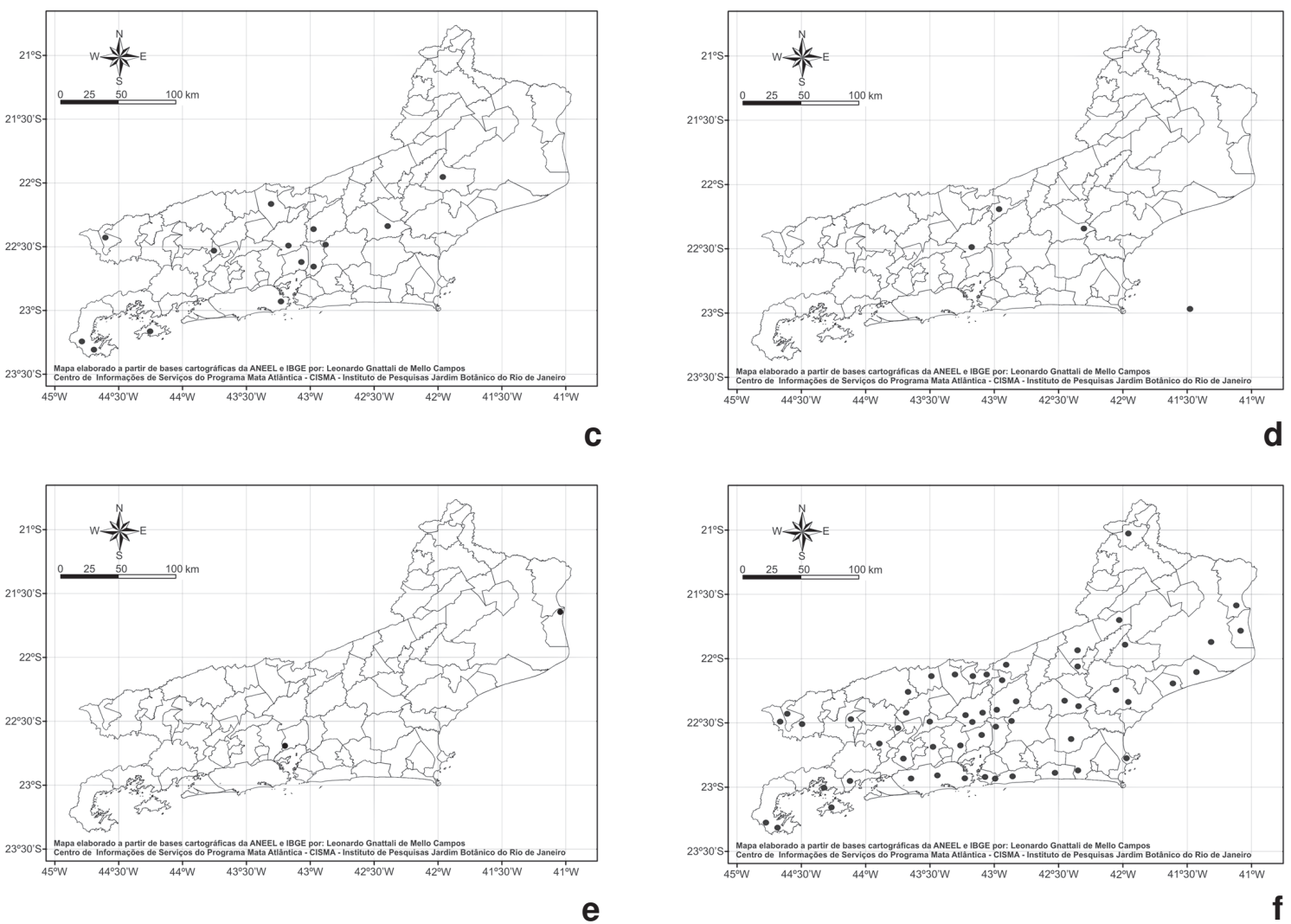

Figura 14 - Distribuição geográfica: a) Casearia obliqua, b) C. oblongifolia, c) C. pauciflora, d) C. selloana, e) C. sessiliflora, f) C. sylvestris.

Faria 166, se alimenta de seus frutos, procedendo-se assim à dispersão das sementes.

Segundo Kuhlmann \& Kühn (1947), os lagartos quando picados por cobras, procuram esta planta, em cujas folhas encontram o antídoto do veneno ofídico, daí o nome "hervade-lagarto".

Casearia sylvestris é amplamente usada na medicina popular como anti-inflamatória, anti-séptica, anti-úlcera e anti-viral (herpes simples labial), segundo Sato et al (1998). As folhas e raízes são depurativas do sangue, moléstias da pele e no combate á sífilis (Siqueira 1981, 1988). Utilizada em forma de chás, também o suco das folhas é usado contra mordedura de cobras, segundo Torres \& Yamamoto (1986) é comprovado no trabalho de Borges (1997). 


\section{Considerações Finais}

No estado do Rio de Janeiro, ao gênero anteriormente representado por dez espécies (Sleumer 1980), foram adicionadas mais duas ocorrências, a saber: Casearia luetzelburgii e C. selloana.

As espécies estudadas possuem distribuição exclusiva no neotrópico. Destas, oito espécies são exclusivas do Brasil, restritas ao nordeste e sudeste, ou alcançam o sul do país. Casearia sessiliflora é endêmica no estado do Rio de Janeiro, mais pontualmente para vegetação de influência marinha (restinga de Mauá, em área secundária, em Campos dos Goitacazes e São João da Barra - Atafona). C. melliodora e $C$. sessiliflora são consideradas como provavelmente extintas no estado do Rio de Janeiro, pela ausência de registros de ocorrência na natureza por mais de 50 anos.

Brade (1954) publicou a contribuição para o conhecimento da flora da serra do Itatiaia, estado do Rio de Janeiro, onde cita para Flacourtiaceae apenas Azara uruguayensis (Speg.) Sleumer. Nosso levantamento, com base em coleções de vários herbários, acrescido de estudos mais recentes apontam C. decandra, C. lasiophylla, C. melliodora, C. obliqua, C. pauciflora e C. sylvestris, como ocorrentes nesta serra.

Casearia aculeata foi citada por Guimarães et al. (1971) como ocorrente no estado da Guanabara, atual município do Rio de Janeiro. Entretanto trata-se de um engano na identificação dos materiais examinados, pois até o momento essa espécie não foi registrada para o estado do Rio de Janeiro, e os respectivos materiais pertencem à espécie C. oblongifolia . Peixoto et al. (1995) citam C. ulmifolia como ocorrente no estado mas, segundo observação do material colecionado em estado vegetativo, podemos constatar que se trata de uma identificação duvidosa e possivelmente pertence à espécie $C$. pauciflora.

\section{Agradecimentos}

Ao Instituto Brasileiro de Geografia e Estatística (IBGE). Ao Instituto de Pesquisas Jardim Botânico do Rio de Janeiro pelas instalações concedidadas na área de Botânica
Sistemática para realização deste trabalho. Aos curadores dos herbários citados pelo acesso ao material botânco, imprescindível para a realização deste trabalho, bem como a gentileza no atendimento. À Dra. Nilda Marquete F. da Silva e ao Dr. Vidal de Freitas Mansano, pelas valiosas sugestões.

\section{REFERÊNCIAS BibLIOGRÁfiCAS}

Alford, Mac H. 2003. Claves para los géneros de Flacourtiaceae de Perú y del Nuevo Mundo. Arnaldoa 10(2): 19-38.

APG II. 2003. An update of the Angiosperm Phylogeny Group classification for the orders and families of flowering plants. Botanical Journal of the Linnean Society 141: 399-436.

Borges, M. H.; Brandenburgo, M. I. H.; Soares, A. M.; Rodrigues, V. M. \& Izidoro, L. F. M. 1998. Ação antipeçonha do extrato vegetal de Casearia_sylvestris. Biotecnologia Ciência \& Desenvolvimento 1(4): 28-30.

Brade, A. C. 1954. Contribuição para o conhecimento da flora da serra do Itatiaia, Brasil. Arquivos do Jardim Botânico do Rio de Janeiro 13: 63-68.

Cambessedes, J. 1829. Samydeae. In: SaintHilaire, A., Jussieu, A. \& Cambessedesm J. Flora Brasiliae Meridionalis. A. Belin Bibliopolam. Paris, 2: 229-238.

Chase, M. W.; Zmarzty, S.; Lledó, K. J.; Swensen, S. M. \& Fay, M. F. 2002. When in doubt, put it in Flacourtiaceae: a molecular phylogenetic analysis based on plastid rbcL DNA sequendes. Kew Bulletin 57: 141-181.

De Candolle, A. P. 1825. Samydeae. In: De Candolle, A. P. (ed.). Prodromus Systematic Naturllis Regni Vegetabilis. Paris (Trenttel et Würtz), Strasburg, London, 2: 47-51.

Eichler, A.W. 1871. Bixaceae. In: Martius, C. F. P. von \& Eichler, A. W. (eds.). Flora brasiliensis 13(4): 421-516.

Gilg, E. 1925. Flacourtiaceae. In: Engler, A. \& Prantl, K. Die Natürlichen Pflanzenfamilien. 2ed. 21:377-457. 
Guimarães, E. F.; Barroso, G. M.; Ichaso, C. L. F. \& Bastos, A. R. 1971. Flora da Guanabara (Flacourtiaceae, Olacaceae, Boraginaceae). Rodriguésia 26(38): 142-171.

Holmgren, P. K.; Holmgren, N. H. \& Barnett, L. C. 1990. Index Herbariorum. Part. 1: The Herbário of the World Regnum Vegetabile. $8^{\text {a }}$ ed. New York Botanical Garden, New York, 693p.

Hooker, J. D. 1867. Samydaceae. In: Bentham, G. \& Hooker, J. D. Genera Plantarum 1: 794-801.

IBGE. Base de dados dos municípios brasileiros. Cidades. Acesso disponível em http://www.ibge.gov.br/cidadesat/ default.php. [consultado em outubro 2004].

Jacquin, N. J. 1760. Enumeratio Systematica Plantarum Insulis Caribaeis 1-41.

Judd, W. S.; Campbell, C. S.; Kellog, E. A.; Stevens, P. F. \& Donoghuc, M. J. 2002. Plants Systematics: a phylogenetic approach. 2ed. Sunderland, Sinauer Associate, Inc., 576p.

Klein, R. M. \& Sleumer, H. O. 1984. Flacourtiaceae. In: Reitz, R. (ed.). Flora Ilustrada Catarinense, Itajaí, Santa Catarina 1: 1-95.

Kuhlmann, M \& Kuhn, E. 1947. Subsídios para o estudo da biocenose regional. In: A flora do Distrito de Ibiti (ex Monte Alegre), Mun. de Amparo. Secretaria de Agricultura, Departamento de Botânica, São Paulo, 221p.

Lawrence, G. H. M. 1973. Taxonomia das plantas vasculares. Vol. 2. Fundação Calouste Gulbenkian, Lisboa, 854p.

Macbride, J. F. 1941. Flora do Peru. Publications of the Field Museum of Natural Botany series 13: 5-50.

Machado, A. O. \& Oliveira, P. E. A. M. 2000. Biologia floral e repordutiva de Casearia grandiflora Camb. (Flacourtiaceae). Revista Brasileira de Botânica 23(3): 283-290.

Marchiori, J.N.C. 1997. Dendrologia das angiospermas das magnoliáceas às flacourtiáceas. Ed. UFSM, Santa Maria, 271p.
Olson, M.; Berry, P. E. \& Aymard, G. A. 1999. Flacourtiaceae. In: Steyemark, J.; Berry, P. E.; Yatskievych, K. \& Holst, B. K. (eds.). Flora of the Venezuelan Guayana 5: 434-472.

Peixoto, A. L.; Rosa, M. M. T.; Barbosa, M. R. V. \& Rodrigues, H. C. 1995. Composição florística da área entorno da represa de Ribeirão das Lajes, Rio de Janeiro, Brasil. Revista da Universidade Rural, série Ciência da Vida 17(1): 51-74.

Rizzini, C. T. 1977. Sistematização terminológica da folha. Rodriguésia 29(42): 103-125.

Sanchotene, M. C. C. 1989. Frutíferas nativas úteis à fauna na arborização urbana. 2 ed. Sagra, Porto Alegre, 306p.

Sato, M. E. O.; Nakashima, T. \& Luz, M. M. S. 1998. Atividade antiviral do extrato aquoso e hidroalcoólico e efeito bacteriostático do extrato fluido de Casearia_sylvestris Sw., Flacourtiaceae. XV Simpósio de Plantas Medicinais do Brasil. Pp.71.

Siqueira, J. C. 1981. Utilização popular das plantas do cerrado. Loyola, São Paulo, 60p. 1988. Plantas medicinais, identificação e uso das espécies do cerrado. Loyola, São Paulo, 40p.

Sleumer, H. O. 1950. Algunas Flacourtiaceas Sudamericanas. Lilloa 23: 247-251. 1953. Las Flacourtiáceas Argentinas. Lilloa 24: 5-56. 1980. Flacourtiaceae. Flora Neotropica Monograph 22: 1-499.

Stearn, W. T. 1983. Botanical Latin, 3rd. rev. 1ed. David \& Charles, London, 566p.

Torres, R. B. \& Yamamoto, K. 1986. Taxonomia das espécies de Casearia Jacquin (Flacourtiaceae) do estado de São Paulo. Revista Brasileira de Botânica 9: 239-258.

Ururahy, J. C. C.; Collares, J. E. R.; Santos, M. M. \& Barreto, R. A. A. 1983. Vegetação. As regiões fitoecológicas, sua natureza e seus recursos econômicos estudos fitogeográfico. Folhas SF.23/24. Rio de Janeiro/Vitória. Projeto RADAMBRASIL Rio de Janeiro. Pp. 553-623. 6 mapas (Levantamento de Recursos Naturais. v. 32). 
Veloso, H. P.; Rangel Filho, A. L. R. \& Lima, J. C. A. 1991. Classificação da vegetação brasileira, adaptada a um sistema universal. IBGE, Rio de Janeiro, 124p.
Walburg, O. 1894. Flacourtiaceae. In: Engler, A. \& Prantl, K. (eds.). Die Natürlichen Pflanzenfamilien. ed. 1, 3, 6a: 1-56.

\section{Índice de Coletores}

s/ col s.n. (RB 82421) (7)

Aguiar, L.F. 23 (12)

Alcântara, I.H. s.n. (GUA 38357) (12)

Almeida, J. 1385 (2)

Altamiro 6(9)

Andreata, R.H.P. 94, 722, 727 (4); 914 (7); 909, 925, 991 (12)

Angeli, C. 335 (7); 68; 536 (12)

Araújo, D. 5257, 8998 (2); 1782, 9231, 9669, 10199 (8); 382, 1179, 1669, 6013, 9151, 10143, 10439, $10491(12)$

Araújo, I.A. 97 (1)

Argolo, A.M. 445 (2)

Barbosa, M.R. s.n. (RBR 6909) (1); s.n. (RBR 6918) (3); s.n. (RBR 6915) (7)

Barbosa, A. 135; s.n. (RB 69585) (12)

Barros, A.A.M. 635, 636, 638, 1024, 1062 (2); 1602, 1949, $1973(12)$

Barros, W.D. 239 (7); 1096 (9); 2 (12)

Barroso, L. 2425 (2)

Boudet Fernandes, H.Q. 355 (12)

Bove, C.P. 14 (2)

Bovini, M.G. 1844, s.n. (RUSU 5602) (2); 2244 (8); 412, 911 (9); 447, 802, 1020, 1841, 2435 (12)

Brade, A.C. s.n. (R 203884, 203885, 203886, 26770) (1); 10974; 11140; 18563 (2); 18824 (7); 11406 (8); 10543; 10591; 16454; s.n. (R 26766) (9); 9753; 11810; $10871(12)$

Braga, J.M.A. 1226, 6304, 6425, 6854 (1); 495, 646, 1097, 4896 (2); 631, 6248 (3); 6802 (8); 1011, 1622, 3361, 3923, 7609 (9); 2302, 2507, 3561, 3984, 4024, 4948, 6065, 7669(12)

Braumgratz, J.F. s.n. (RB 291565) (1)

Britto, Y. 160 (12)

Britto Pereira, C.E. 171, 298 (12)

Campell, P. S.J. s.n. (FCAB 1303) (1); (FCAB: 1305) (6); s.n. (FCAB 1308) (9)

Campos, B.B. s.n. (RBR 7545) (2); (RBR 7546) (7); (RBR 7544) (12)
Canella, C.F.C. s.n. (RB 288225) (12)

Carauta, J.P.P. 5689 (1); 338, 6171 (2); 1693 (7); 2454 (9); 842, 1188, 2075, 2078, 5847, 5862, 6243 (12)

Carcerelli, C. 96 (1); 13 (12)

Cardoso, L.J.T. 218, 227 (9)

Carvalho, L.D'A. F. s.n. (RB 270318, 270330, 281665) (7); 517 (12)

Carvalho, W.B. 203, 206, 232 (2); 123 (12)

Casari, M.B. 338 (2); 1170 (9); 323 (12)

Clarindo s.n. (RB 4971) (12)

Cominote, J. 19 (12)

Conde, M. 475 (1)

Conde, M.M.S. 334 A, 425, 461 (12)

Constantino, D. s.n. (RB 7685) (8); 17, 67, s.n. (RB 3296) (9); 60 (12)

Correia, C.M.B. s.n. (RB 291900) (1); s.n. (RB 291905, 291907, 291908) (7); s.n. (RB 291569), s.n. (RB 291570), s.n. (RB 291572), 84, 252 (12)

Costa, E. 244 (12)

Curitiba, T.A.M. 58 (12)

Duarte, A.P. 419, 5534 (1); 4461; 5621, s.n. (RB 73383) (2); 4995 (3); 8447 (5); 54, s.n. (RB 60833), 967, 5425; 5426 (7); 4795 (8); 4769, 4872, 4890, 4911, 4917, 4951, 4969, 5257 (12)

Duarte, C. 110, 154 (12)

Ducke, A. (RB 3293) (8)

Eraldo 6 (12)

Escragnolle s.n. (R 51730, 90003) (1)

Faria, D.S. 176 (1); 258 (2); 166 (12)

Farney, C. 953 (2); $1162(3) ; 4160(4) ; 4313$ (7); 3207 (8); 3205, 3206, 3298, 4158 (12)

Ferreira, V.F. 3887 (2); 261 (9); 2238 (12)

Flores, D. 139 (2)

Flores Lima, D. 79 (2)

Fonseca, V.S. 286 (12)

Fontella, J.P. 3108 (8); 167, 172 (12)

Fontoura, T. s.n. (RB 291906) (7)

Forzza, R.C. 2798 (12) 
Frazão, A. s.n. (RB 7026, 10603) (1); s.n. (RB 7455)

(2); s.n. (RB7458) (7); s.n. (RB 7457) (12)

Frutuoso, L.C.F. 81 (9)

Garcia, R. 12 (7)

Giordano, L.C. 1699 (9); 1305 (12)

Glaziou 845, 10244 (1); 1507 (2); 6198 (3); 2896a (5); 4205 (8); 2564 (9); 1389, 8267 (12)

Góes, O.C. 37, 547, 713, 744, 1003 (1); 810 (7); 68, 1055 (9); 324, 431 (10); 74, 77, 381, 777 (12)

Gomes, M. 108 (7); 40 (12)

Gomes, M.L. 1 (12)

Gonçalves, S. 11 (9)

Gonçalves, S.B. 78, 134 (12)

Gonçalves, V.F. 27 (2)

Guedes, R. 2175(1);s.n.(RB 291910,291911,291912)(3); 2231,s.n.(RB 291903)(9);s.n.(RB 291909,314242)(12)

Guerra, F. s.n. (RB 47479) (2)

Guimarães, E.F. 91 (1)

Hemmendorff, E. 424, 465 (11)

Hoehne, F.C. s.n. (IAC 40625) (2)

Ichaso, C.L.F. 63, 82 (2)

Jesus, J.A. 1610 (12)

Josué 1 (9)

Konno, T. 64 (2); 96 (9); 56, 296 (12)

Kuhlmann, J.G. s.n. (RB 5228) (1); s.n. (RB 16283) (2); 6105, s.n. (RB 16278, 18997), s.n. (RB 102307) (3); s.n. (FCAB 1304), s.n. (IAC 42779); s.n. (RB 46952) (7); s.n. (RB 129455) (8); s.n. (RB 129458) (9); s.n. (RB 129459) (12)

Kurtz, B.C. s.n. (RB 291914) (3); s.n. (RB 328338) (9); 261 (12)

Lachette, P. 219 (8)

Lanna Sobrinho, J.P. 1221 (7); 87, 901 (12)

Lanystyak, L. 222 (12)

Leitman, M. 25, 416 (1)

Lemos Ramos, M.C. 910, 938, 939, 945, 1717, 1782 (7); 1856(12)

Lima, H.C. s.n.(R 291568)(1);2196(2); s.n. (RB 291913) (3); 4568 (8); 2344, 2322, 3444 (9); 83, 3554, 3805; s.n. (RB, RUSU 4505) (12)

Lima, M.P.M. s.n. (RB 314237) (12)

Lira, C.M.S 226 (2)

Lira Neto, J.A. 65 (2)

Lisboa, A. (RB 2722) (6)

Loureiro, R. 8 (12)

Lourenço Gomes, A. 73 1⁄2 (12)

Luchiari, C. 95, 169, 477 (1); 1 (12)

Lutz, A. 860, 1070, 1145 (2); 1071 (12)

Lutz, B. 985, 2068 (2); 2016 (12)

Machado, O. 87 (12)
Marquete, R. 2970, 3453, 3454, 3455, 3456, 3457 , 3467, 3503 (1); 540, 581, 637, 1024, 1991, 2348, 2350, 2815, 2873, 3013, 3404 (2); 3377 (3); 3474, 3475 (4); 3476 (7); 1268, 1421 (8); 1817, 3562, 3573 (9); 3304 (10); 1088, 1750, 2145, 2167, 2179, 2349, 2390, 2391, 2392, 2804, 2805, 2927, 2930, 3285, $3297,3352,3374,3391,3451,3465,3468,3469$, $3470,3471,3477,3478,3486,3511,3512,3514$, $3521,3522,3526,3535,3536,3545,3546,3547$, $3551,3558,3560,3561,3567$ (12)

Martinelli, G. 2825, 3096, 3180 (2); 132 (7); 3055, 10000, 10139, 10191 (9); 952, 3255, 10542, 10784 (12)

Martins, E.M.O. s.n. (RFA 17429) (12)

Martins, H.F. 305 (9)

Matos, V.C. 35 (2)

Mattos Filho, A. 89 (7)

Mello, O.S. s.n. (RB 82419) (12)

Mello Filho, L.E. 76, 1484, 5269 (2); 5255 (8)

Menezes, L.F.T. 806 (1); 209, 508, s.n. (RBR 6481), s.n. (RBR 6483) (2)

Monteiro, M.A. s.n. (RB 68464) (2)

Monteiro-Filho, H. 1415, 1426, 1442, 1449, 1847, 2017, 2759 (2); 983, 2413, 3190 (7); 2774, 3628(12)

Moraes, M. S. 19 (9)

Moura, M.V.L.P. 629, s.n. (RBR 7551) (12)

Nadruz, M. 536 (1); 264, 594 (12)

Neves Armond, W. 317 (12)

Occhioni, E.M. 487, 503, 507, 531, 538, 544 (2)

Occhioni, P. 6374, 6516, 7024 (1); 587, 613, 7875 (2); 186 (8); 1411, 1420, 7156, s.n. (RB 277) (9); 185 , 576, 3567, 7478, 7509, 7641, 7939, 8597 (12)

Oliveira, C.A.L. 1352 (1); 289 (2); 770, 1715 (7); 286, 346, 772 (9); 793, $1169(12)$

Oliveira, R.F. 487 (2)

Pabst, G.F.J. 4361, 4560, 7001 (2); 8269 (3); 4646, 6797 (7); 4230, 6997, 7000 (12)

Passarelli, A. 125 (2)

Peckolt s.n. (R 36354) (2)

Pedrosa, D.S. 1383 (1).

Peixoto, A.L. 6257, 6332 (7); 6223, 6233, 6280 (12)

Peixoto, GL. 033(2);078 (4);070(7);068,069,079(12)

Peixoto 949, 950 (12)

Pereira, C. s.n. (RB 275217) (12)

Pereira, E. 19, 3925, 4368 7099, s.n. (HB 22840) (2); 1926, s.n. (RFA 5929) (7); 190, 4229 (9); 81, 396, $528,3885,5117(12)$

Pereira, F.M.B. 8/13, 22/039, 29/24 (1); 07/29, 21/ 039, 25/66, 261 (2); 13/039 (RFA 16863), (8); 49/49 (RFA 25781) (10); 1-10 (RFA 23934), 14/24 (RFA 24847), 236(12) 
Pereira, J.F. 42 (2)

Pereira, T.S. s.n. (RB 296443, 296444, 296464) (1)

Pereira 4226 (7)

Pessoa, S.V.A. 836, s.n.(RB328561)(1); s.n.(RB314235)

(2); 667 (8); 701, 797, s.n.(RB 314239, 314241) (12)

Pessoal do Horto Florestal s.n. (RB 129447, 129448)

(1); s.n. (RB 129449, 129462) (2); s.n. (RB 129457)

(3); s.n. (RB 129451, 129450) (7); s.n. (RB 129456)

(8); s.n. (RB 129460) (12)

Pineschi, R.B. 2, 246 (12)

Pinheiro, F. 795 (9)

Pinto, L.J.S. 387 (2)

Piratininga, A. 26, 70 (1); $106(8) ; 66(12)$

Porto, P.C. s.n. (RB 10599) (3); 740 (5); s.n. (RB 10601), 733, s.n. (RB 21432) (6); 684, 2666 (7)

Quinet, A. 463 (1); 09 (2); 362, 559, 567, 01/62 (3); s.n. (RB 21432) (9); 18/94 (RFA 27847) (10); 13/39 (RFA 27623), 14/91 (RFA 27680), $17 / 94$ (RFA 27846), 35/94 (RFA 27863), s.n. (RB 10598) (12)

Reis, R. 156 (12)

Ribeiro, R. 1199 (1); 282, 628 (2); 773, 1990 (9); 505, 1161, 1189, 1205, 2004 (12)

Richter, E. s.n. (HB 10375, 10506) (2)

Rizzini, C.M. 150 (2); 169 (5)

Rizzini, C.T. 10052 (3)

Rodrigues, I.A. 117, 171 (2)

Rosa, M.M.T. 406 (12)

Saldanha, J. 4981 (1); s.n. (R 51670) (2); s.n. (R 51698) (8); s.n. (R 51747), s.n. (R 51755) (9); s.n. (R 51712), 946b (12)

Sampaio, A.J. (R 51750) (1); 2441 (9); 2992 (11); 2127, 2303, 4874, 8751 (12)

Sampaio, F.M. 4 (2); s.n. (R 79911) (12)

Santos, M. 32 (2)

Scheel-Ybert, R. 333 (9); 350 (12)

Schettino, V. 335 (2)

Schuback, P. 03/52 (RFA 25446) (12)
Schwacke s.n. (R 51697) (9); s.n. (R 51713, 90014) (12)

Sellow, F. 240 (1)

Silva, F.G. 136(12)

Silva, G.M. 30 (12)

Silva, I. 289 (12)

Silva, I.M. s.n. (RBR 6912) (1); 34b (2); 379 (12)

Silva, J.F. s.n. (RB 191583, 191595) (2)

Silva, L.C. S. s.n. (RB 296445) (1)

Silva, O. A. s.n. (RB 18282) (12)

Silva Neto, S.J. 1497 (1); 449, 728, 1848 (12)

Sommer, G.V. 13c(3)

Sonkin, L. 345 (9)

Souto, S.M. 181, 196, 324, 593 (12)

Souza Brito (RBR 6914) (6)

Spolidoro, M.L.C.V. 107, 163, s.n. (RBR 5010) (1); 277 (7); 161, s.n. (RBR 5012, 5013) (12)

St.- Hilaire, A. cat. B2 nº 218 (11)

Strang, H.E. 165 (12)

Sucre, D. 1658, 1714, 1751 (1); 5301, 6351, 7597 (2); 4281 (7); 2546, 7454, 8509, 9142, 10705 (9); 3984, 4203 (10); 2680, 3304, 3469, $3486(12)$

Tatto, L. s.n. (RB 47289) (7)

Trinta, Z.A. 495 (2)

Ule, E. 14; s.n. (R 51663) (2)

Vaz, A.M.S.F. 419 (2)

Velloso, H.P. s.n. (R 38400) (9); 444; s.n. (R 38405) (12)

Vianna, M.C. 1631 (1); 1322, 1600, 1612, 1821 (12)

Vidal, J. s.n. (R 51665) (2); s.n. (R 51634) (8); 5811 (9); 6769(12)

Viegas, A.P. 2393 (2)

Vieira, C.M. 227 (1); 433 (3); 313, 353 (12)

Vilela, M.L. 31 et al. (1)

Widgren s.n. (R 51709) (12)

Xavier, L. s.n. (RBR 6933) (2)

Xavier Moreira, A. s.n. (R 103810) (1)

Zaú, A.S. 25 (1)

Zysko, C.C. 164 (9) 